\title{
Soil erosion risk and sediment yield assessment with universal soil loss equation and GIS: in Dijo watershed, Rift valley Basin of Ethiopia
}

\author{
Bagegnehu Bekele $^{1}$ (D) Yenealem Gemi $^{1}$
}

Received: 29 July 2020 / Accepted: 17 October 2020 / Published online: 10 November 2020

(c) The Author(s) 2020

\begin{abstract}
Soil erosion is the main drivers in the world and Ethiopia in particular. This study has been conducted at Dijo watersheds in the Rift valley Basins of Ethiopia to estimate soil erosion rate and identify erosion hotspot areas for proper planning using Geographic Information System and Universal Soil Loss Equation adapted to Ethiopian condition. 64 years mean annual rainfall data for estimating erosivity factor, digital soil map for estimating soil erodibility factor, Digital Elevation Model for estimating topographic (LS) factor, Land use land cover for cover factor detection from Ethiopian ministry of water resources. The result reveals that the soil loss ranges from 0 ton/ha/year in flat slope to 38.09 ton/ha/year from steep slopes. The average soil loss rate is 2.2 tons per hectare per year and has been classified into three erosion severity classes as very low, low and moderate. The result also reveals that most of the watershed erosion severity evaluated under very low and low soil erosion severity classes covering $97.3 \%$ of the watershed areas which is due to the effect of mixed plantation of various tree and terraces. However, moderate soil erosion in the upper parts of the watershed could be due to the inherent characteristics of vertisols, lack of vegetation cover and terraces which should be given first priority for conservation interventions. From the gross soil erosion, 43,762 ton/year sediment yields have been estimated at watershed outlet. Policy aim at keeping land productivity will need to focus to reduce low and moderate soil erosion through terracing, inter-cropping, contour farming, strip cropping, conservation tillage, mulching and biological stabilizers based on their slope range, soil type and land use type. The current finding on erosion was evaluated based on the past 10 years land use land cover scenario; therefore, soil erosion might be reduced if the current land use land cover scenario considered. Finally, the integration of USLE and GIS is an effective tool in mapping the spatial distribution of soil erosion from the entire watershed. The moderate and low soil erosion severity areas should be managed through terracing, inter-cropping, contour farming, strip cropping, conservation tillage, mulching and biological stabilizers based on their slope range, soil type and land use type. Free grazing and cultivation of steep slope(Northern parts) contributed for moderate soil erosion in the watershed should be managed by cut-carry system, limiting the number of cattle units to be grazed in the specific plot of land and leaving the marginal steep slope areas with no ground covers for natural regeneration. Finally, the current finding on erosion was evaluated based on the past 10-year land use land cover scenario. Therefore, the soil erosion could be reduced if the current land use land cover scenario is considered.
\end{abstract}

Keywords Conservation priority $\cdot$ Dijo watershed $\cdot$ Sediment yield $\cdot$ Soil erosion $\cdot$ Sub-watersheds $\cdot$ GIS $\cdot$ USLE $\cdot$ SLMP

\section{Abbreviations \\ DEM Digital elevation model \\ FAO Food and agricultural organization}

Electronic supplementary material The online version of this article (https://doi.org/10.1007/s40808-020-01017-z) contains supplementary material, which is available to authorized users.

Bagegnehu Bekele

bagegnehubekele@gmail.com

1 Worabe Agricultural Research Center, South Agricultural Research Institute, Ethiopia, P. BOX. 21, Worabe, Ethiopia
USLE Universal soil loss equation

SCRP Soil conservation research program

yr Year

LULC Land use land cover

ha Hectare

WBISPP Woody biomass inventory and strategic planning project 


\section{Introduction}

At a global scale, water erosion is the main cause off soil degradation (Deniz et al. 2008) and about $80 \%$ of the world's agricultural land suffers from moderate to severe erosion (Ritchie et al. 2003). Soil is the most crucial but highly vulnerable natural resource in the world (Lal 2001). Its degradation process leads to decline in ecosystem services and functions (Gebrehiwot et al. 2014). It is also one of the biggest threats in Ethiopian highland which threatens agricultural productivity. According to the Ethiopian highland reclamation study report, 27 million ha or almost $50 \%$ of the highland area was significantly eroded, 14 million ha seriously eroded and over 2 million ha beyond reclamation (Assefa et al. 2015).

Soil erosion has on-site and off-site effect; soil quality and productivity as on-site effect (Haregeweyn et al. 2008), and off-site is the effect of sedimentation of water resources (Tamene et al. 2011). The off-site effect also generates deposition of soil materials in the reservoirs, irrigation schemes and waterways downstream (Cerdà and Doerr 2008).

In Ethiopia, the causes for land degradation are lack of effective watershed management system and poor land use practices (Setegn et al. 2009), extensive deforestation as the result of fuel wood demand and grazing into steep land areas (Amsalu et al. 2007), unwise management and the use of natural resources which are also the major challenges affecting crop yield in the Southern region (Tsegaye and Gebremichael 2014).

There are many erosion prediction models worldwide. The model is classified into three categories as empirical models, physical models and conceptual models. The use of models depends on the availability or adequacy of input data. Empirical models are models based on inductive logic, and generally are applicable only to those conditions for which the parameters have been calibrated or used for identifying the sources of sediments since they are developed from the experimental measurement or field measurement (Merritt et al. 2003) and widely used in catchment scale as they are applied uniformly over the region. However, they are unable to analyze the dynamics of sediment erosion and deposition in the watershed as it contains fewer amounts of input data. Physical models are models which are based on solving fundamental physical equations describing stream flow and sediment and associated nutrient generations in a specific catchment (Merritt et al. 2003). The demerit of this model is the requirement of large amount of data. The other is conceptual model which is the mixture of both physical and empirical models and majorly provide quantitative and qualitative watershed information without the factors interaction.

Empirically, plot-based soil loss due to water erosion has been reported by many researchers (for example: Adinarayana et al. 1999; Veihe et al. 2001). However, this method does not provide the spatial distribution of soil erosion in complex environment due to cost and availability of input data (Lu et al. 2004). Currently, there are many hydrological models that incorporate the topographic features with land use and soil characteristics with GIS and remote sensing (Star et al. 1997). Universal Soil Loss Equation (USLE)(Wischmeier and Smith 1965) and Revised Universal Soil Loss Equation(RUSLE) are the common and widely used equations in erosion modeling (Fistikogli and Harmancioglu 2002), However, USLE model has been widely used as it combines the impact of climate, soil, topography and land use on soil loss with limited data (Wischmeier and smith 1978). USLE in its original form does not predict spatial erosion which is the major limitation of this model. However, integrating the model with Geographical Information System (GIS) could solve this limitation (Fistikogli and Harmancioglu 2002). Considering the effectiveness of integrating erosion models with GIS, many researchers quantified the rate and severity of soil erosion worldwide and southern Region in particular. Based on the modeling, Soil Conservation Research Project (SCRP) estimated that about 1.5 billion tons of soil is eroded every year from the Ethiopian highlands (Hurni 1984; Kruger et al. 1995). FAO (1984) and Hurni (1993) also reported annual soil loss from Ethiopian highlands to be 200-300 tons ha $\mathrm{ha}^{-1}$ year $^{-1}$. Similarly, Hurni et al. (2008) estimated that soil loss due to erosion of cultivated fields under standard conditions in Ethiopia amounts to about 42 tons $\mathrm{ha}^{-1}$ year $^{-1}$. The study of Bekele et al. (2019) from Karesa watershed reported the gross erosion as $42,413.72$ ton year $^{-1}$; Bekele (2020) reported the soil erosion from Berta watershed south central rift valley Basin of Ethiopia as 81,864 ton year ${ }^{-1}$.

Dijo watershed is the largest watershed in Rift valley Basin of Ethiopia. Land degradation in the form of soil erosion is the major problems affecting agricultural productivity. Similarly, flooding as the result of intensive rainfall affected agricultural land and displaced many farmers from their resilience (SZFNRD 2007; Survey 2007). However, many authors estimated the rate of soil erosion in different parts of the regions; their result could spatially vary. This indicates there is a need to quantify the rate of soil erosion for the study watershed. Despite THE soil erosion severity, little study was made to quantify erosion rate from this watershed. Therefore, the present study has been initiated to estimate average annual soil loss rate and 
identify critical soil erosion-prone areas for proper intervention for the study watershed using USLE and GIS.

\section{Materials and methods}

\section{Study area description}

\section{Geographical location}

Dijo watershed is located in Rift valley Basin of Ethiopia. It is found in Administrative boundaries of Silte zone, Southern Nation Nationalities and Peoples Region (SNNPR). The watershed comprises Alicho wuriro, Silti, Dalocha, Hulbareg, Sankura woredas, including Worabe town and geographically located between $38^{\circ} 27^{\prime} 0^{\prime \prime} \mathrm{E}$ $-38^{\circ} 50^{\prime} 30^{\prime \prime}$ E longitude and $7^{\circ} 27^{\prime} 30^{\prime \prime} \mathrm{N}-8^{\circ} 01^{\prime} 00^{\prime \prime} \mathrm{N}$ latitude. The watershed covers 123,395 Ha. (Fig. 1).

\section{Climate}

\section{Rainfall pattern of the area}

Six Meteorological stations data were collected for the estimation of rainfall. Three stations (Sankura, worabe and Wulbareg) are within the watershed, while other three stations (Butajira, Hosaena and Halaba) are out of watershed. The watershed annual rainfall of the study area ranges from $912.4 \mathrm{~mm}$ to $1160.8 \mathrm{~mm}$. The average annual precipitation of the area is $1003.7 \mathrm{~mm}$. The rainfall is uni-modal type with one long rainy season. April, May, Jun, Jul, Aug and Sep receive $>100 \mathrm{~mm}$ average annual rainfall and among the three stations, Hulbareg station receives peak rainfall in July and August. All the meteorological stations receive $<50 \mathrm{~mm}$ average rainfall during January, February, November and December as shown in (Fig. 2).
Fig. 1 Location map of the study watershed

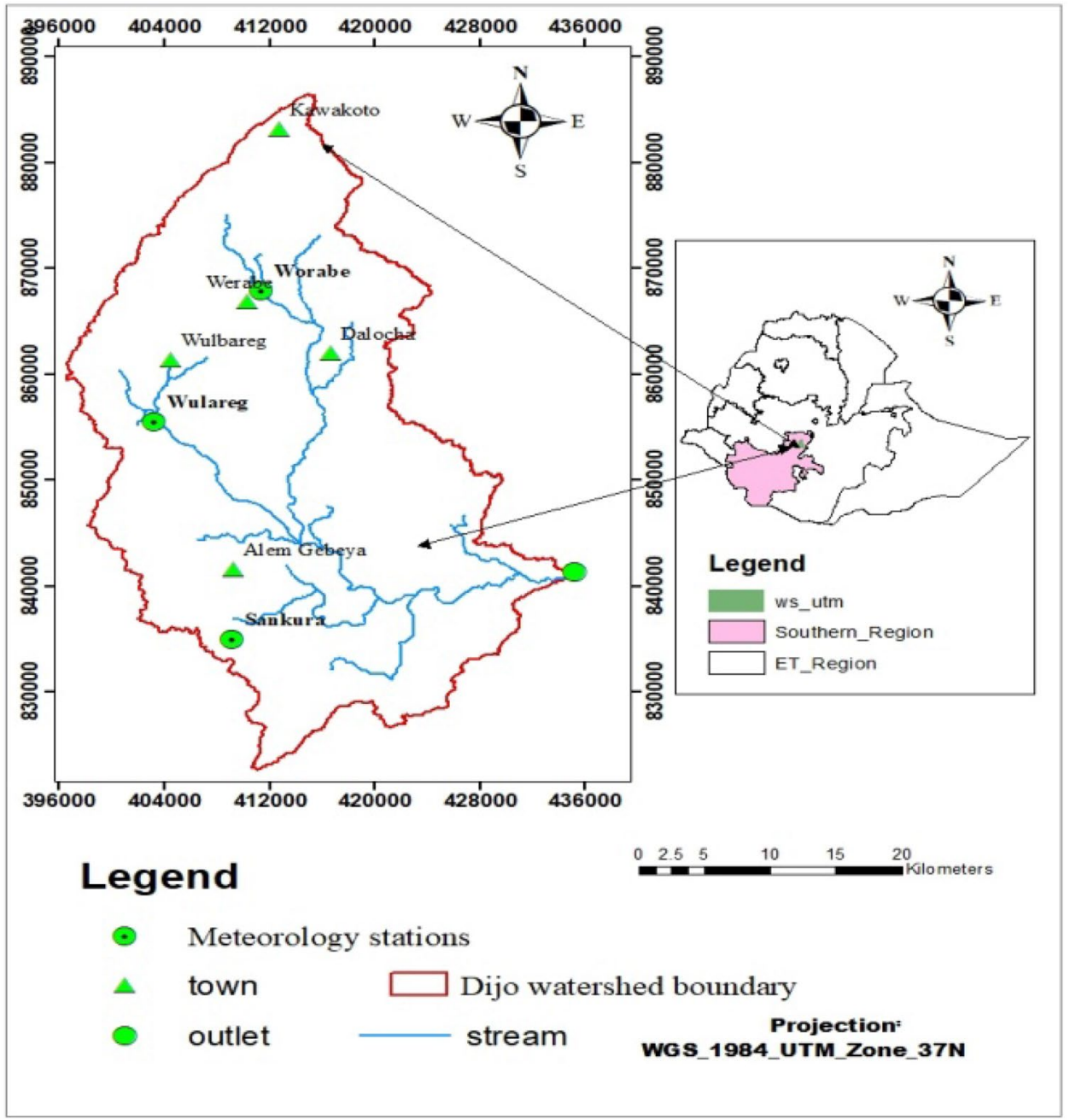


Fig. 2 Long year stations average annual rainfall

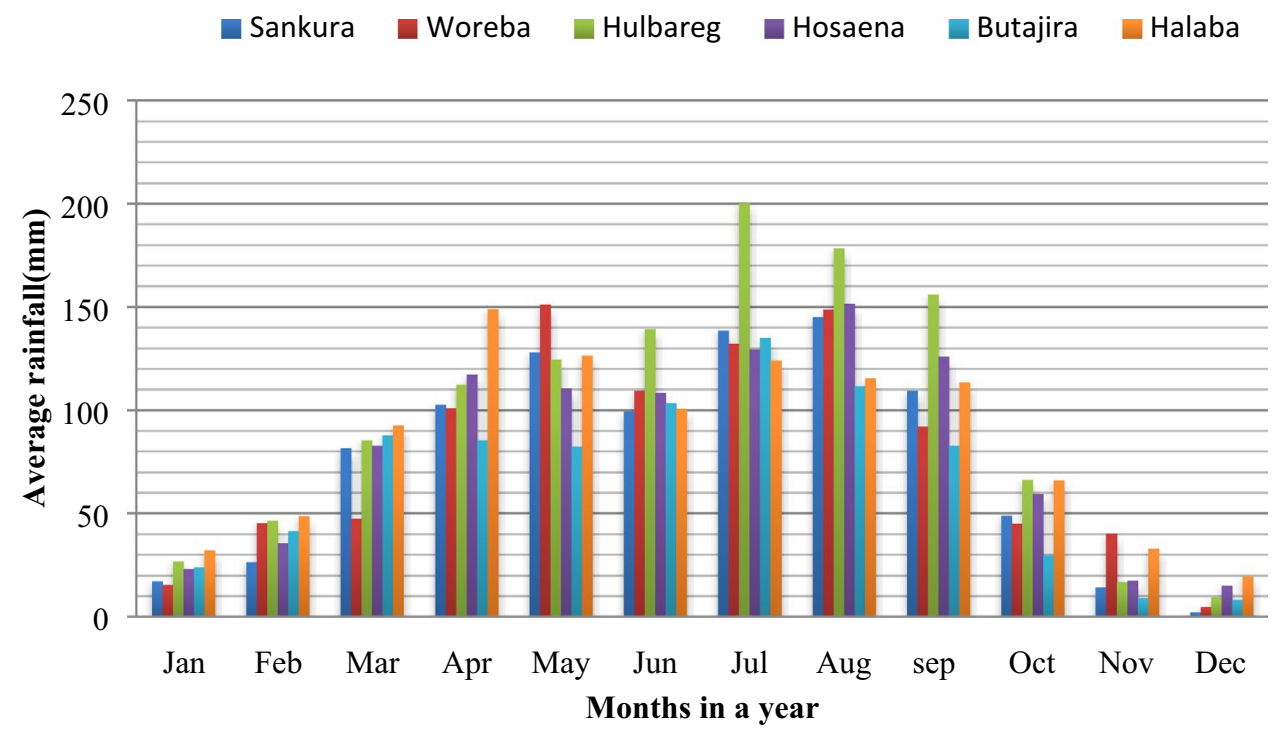

Table 1 Land use land cover types of Dijo watershed

\begin{tabular}{lcc}
\hline Land use & Area ha & \% of total \\
\hline Open shrub lands & 350.84 & 0.4 \\
Closed shrub lands & 916.28 & 0.8 \\
Mixed plantation & $55,307.4$ & 44.8 \\
Woody savannas & 3294.35 & 2.6 \\
Savannas & 791.37 & 0.6 \\
Cultivated lands & $49,864.2$ & 40.4 \\
Grass lands & $12,870.7$ & 10.4 \\
\hline
\end{tabular}

\section{Land use land cover of the study area}

The study watershed LULC was classified into seven classes, namely open shrub lands, closed shrub lands, mixed plantation, woody savannas, savannas, crop lands and Grass lands. Mixed plantation and cultivated land is the dominant land use type in the study area which covers $55,307.4(44.8 \%)$ and $49,864.2(40.4)$ of the total study area, respectively; while other land use covers $14.8 \%$ (Table 1). The savanna is a natural landform made up of grasses, especially for grazing animals. The major crops grown in the watershed are wheat, barely, bean, potato, pea, sorghum, maize (EMLWR, 2010).

\section{Topography}

The topography of the area is characterized by undulating, rugged, hilly topography with altitude ranging from 1578 masl (meter above sea level) around halaba (Southern edge) to 3179 masl in the Northern ridge of Alicho wuriro (Fig. 3).

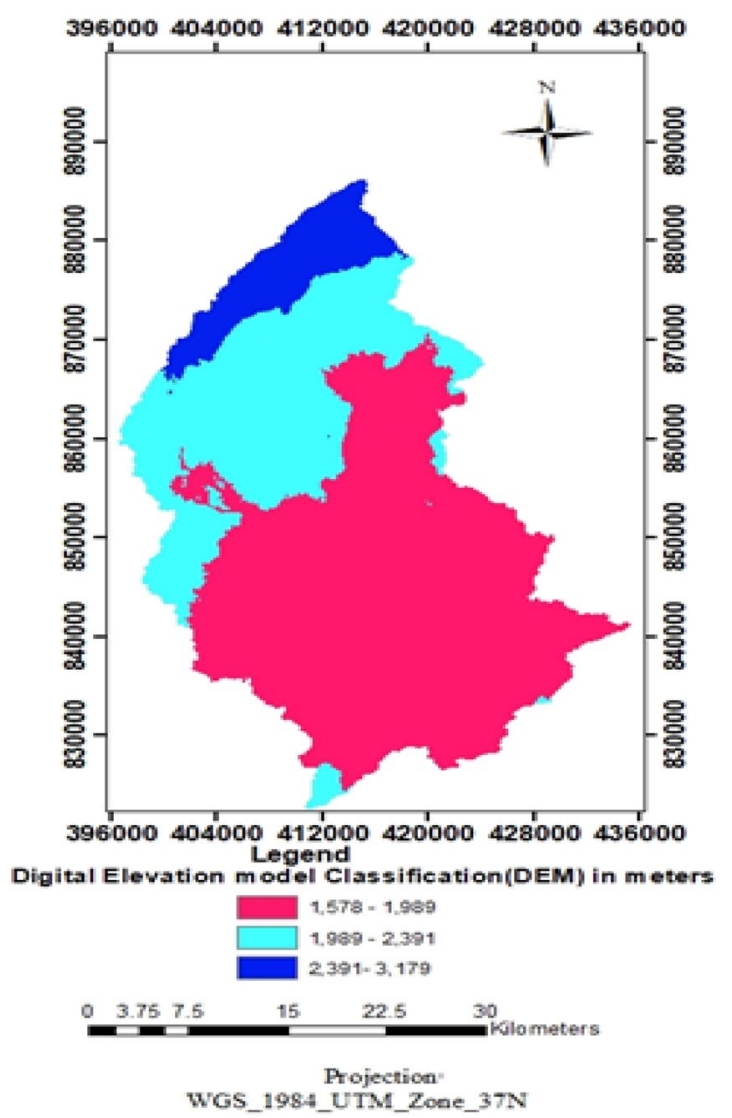

Fig. 3 Digital elevation map of the study watershed

\section{Slope}

Based on the $30 \mathrm{~m} \times 30 \mathrm{~m}$ resolution of DEM, the slope of the watershed is classified into 8 classes as shown in Table 2 
Table 2 Slope coverage (modified from FAO 2006) and area coverage of Dijo watershed

\begin{tabular}{llcc}
\hline Slope classes & Slope $\%$ & Area coverage (Ha) & Area ratio (\%) \\
\hline Level slope & $<1$ & 2407 & 2.0 \\
Very gentle sloping & $1-2$ & 10,919 & 8.8 \\
Gently sloping & $2-5$ & 39,264 & 31.8 \\
Sloping & $5-10$ & 38,706 & 31.4 \\
Strongly sloping & $10-15$ & 16,700 & 13.5 \\
Moderately steep & $15-30$ & 12,981 & 10.5 \\
Steep & $30-45$ & 1810 & 1.5 \\
Very steep & $>45$ & 608 & 0.5 \\
& & 123,395 & 100 \\
\hline
\end{tabular}

below with dominantly Gently sloping and Sloping followed by Strongly sloping and Very gentle sloping (FAO 2006).

\section{Soil}

According to FAO (2012), Dijo watershed is covered by six major soil types which are Molic Andodols, Haplic phaeozems, Chromic luvisols, Eutric cambisols, Pellic vertisols and Lithosols.

\section{Methods of determining USLE factors}

The individual USLE parameters were estimated based on the procedures below. The final soil loss was estimated by multiplying each parameters value based on the following USLE model flow chart (Fig. 4).

\section{Rainfall erosivity (R_factor)}

Erosivity of rain is the product of storm kinetic energy (KE) and maximum 30-min intensity (EI30) (Renard et al. 1997). But, the data on rainfall kinetic energy and rainfall intensity are limited in Ethiopia to compute rainfall erosivity. 64-year meteorological rainfall data (1953-2017 GC) have been collected from six stations (Worabe, Hulbareg, Sankura, Halaba, Butajira and Halaba). Missing rainfall data for all stations have been filled using nearest neighborhood interpolation technique. R_factor has been calculated for each station using mean annual rainfall data from regression equation developed by Kaltenrieder (2007) to Ethiopian conditions as shown in Equation [3-1] below using inverse Distance Weighted (IDW) Interpolation, with 12 neighborhoods in spatial analyst tool

$\mathbf{R}=\mathbf{0 . 3 6} * \mathbf{p}+\mathbf{4 7 . 6}$

where $R$ is the rainfall erosivity factor and $P$ is the mean annual rainfall (mm).

\section{Soil erodibility factor (K_factor)}

Soil erodibility $(\mathrm{K})$ is the intrinsic susceptibility of a soil to erosion by runoff and raindrop impact. Its index is defined as mean annual soil loss per unit of erosivity for a standard condition of bare soil, no conservation practice, 5o slope of $22 \mathrm{~m}$ length. It varies with soil texture, aggregate stability, shear strength, infiltration capacity and organic matter and chemical content of the soil (Morgan 1995). The study area soil groups were clipped from FAO (2012) digital soil map using spatial analyst tool in
Fig. 4 Flow chart of USLE model to estimate soil loss rate in Arc GIS environment

\section{UNIVERSAL SOIL LOSS EQUATION ANALYSIS IN GIS}

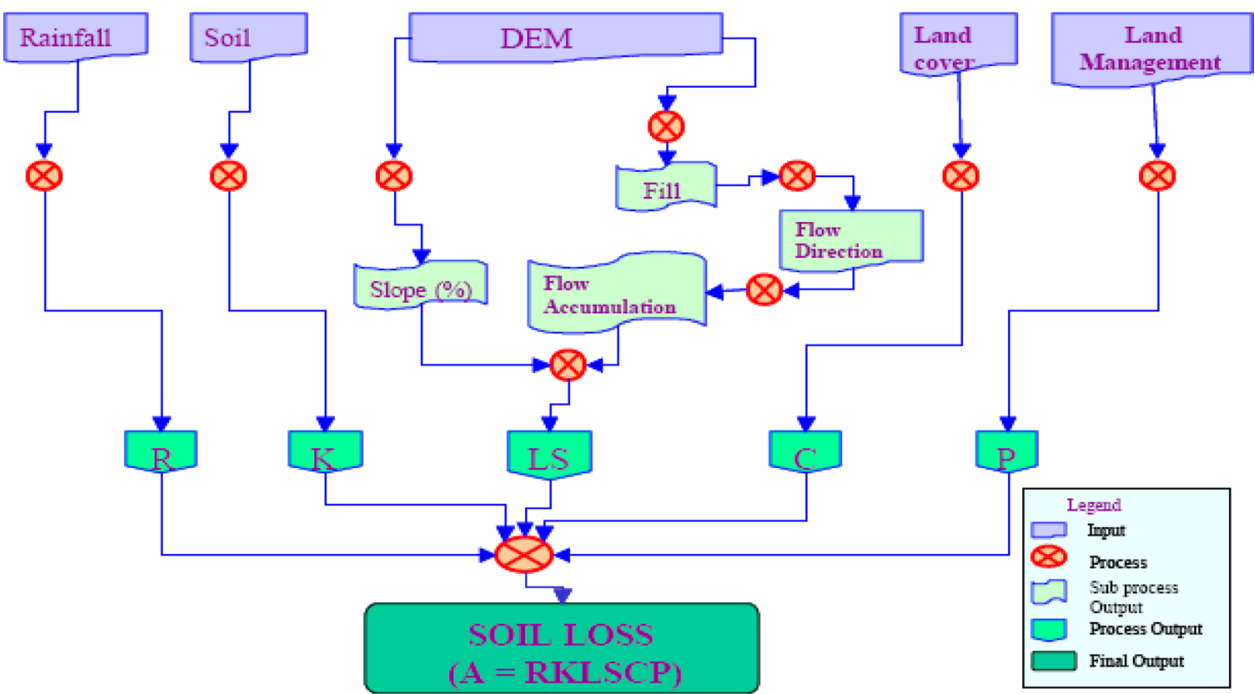


Arc GIS Environment. Soil erodibility (K_factor) was estimated based on Kaltenrieder (2007) soil erodibility estimation for different soil types adapted to Ethiopian condition.

Soil textural nomograph is widely used to determine the soil erodibility values. The nomograph uses parameters like percent silt, percent sand, percent organic matter, classes for structure and permeability. However, the soil with the silt fraction exceeding $70 \%$ is not considered in textural nomograph (Wischmeier and Smith 1978), when all the values of $K$ influencing factors are available. Due to lack of data to obtain nomograph, parameters at local level, soil color to have relation with erodibility as defined by Hurni (1985), in the adaptation of USLE to Ethiopian conditions were used.

The k_value has been assigned to each soil type based on their colors (Table 3 ) and the resulting shape file was changed into raster formats of $30 \mathrm{~m} \times 30 \mathrm{~m}$ cell resolution. Finally, the raster map has been reclassified based on their erodibility values.

\section{Slope length and slope steepness factor (LS_factor)}

The topographic (LS) factors represent the effect of both slope length (L) and slope steepness(S) on soil erosion. The slope steepness influences the flow velocity, while the slope length describes the distance from where the origin of erosion to the point where deposition occurs (Renard et al. 1997). Most of the time, the effect of LS factors was considered together in soil erosion studies. LS were calculated by unit stream power Erosion and Deposition methods which use both flow accumulation and watershed slope (Pelton et al. 2012). To remove the depression, the original $30 \mathrm{~m} \times 30 \mathrm{~m}$ cell resolution DEM were filled, flow direction, flow accumulation and slope in degree was computed in ArcGis environment. Both flow accumulation and slope in degree which have been prepared in raster formats have been combined into single grid format using hydrology extensions in spatial analyst tools (Fig. 8)

$$
\begin{aligned}
\mathrm{LS}= & (\text { Flow Accumulation } * \text { Cell size } / 22.13)^{0.4} \\
& *(\text { Sin slope } / 0.0896)^{1.3}
\end{aligned}
$$

where cell size represents the resolution of the grid $(30 \mathrm{~m})$ and 22.13 is the standard field slope length; flow

Table 3 Soil Erodibility K-Factor Estimated

\begin{tabular}{lllll}
\hline Soil color & Black & Brown & Red & Yellow \\
\hline K_factor & 0.15 & 0.2 & 0.25 & 0.3 \\
\hline
\end{tabular}

Source: Helldén (1987) accumulation is the number of cells contributing flow into a given cell.

\section{Cover factor (C_factor)}

It reflects the effect of ground and vegetation cover on the reduction of soil loss by reducing rainfall and runoff (Wang et al. 2003). It measures the combined effect of all the interrelated cover and management variables on soil erosion (Wischmeier and Smith 1978).

The $\mathrm{C}$ Factor is dimensionless and varies from 1 on bare soil to $1 / 1000$ under forest, $1 / 100$ under grasslands and cover plants, and 1 to $9 / 10$ under root and tuber crops (Wischmeier and Smith 1978). The Dijo watershed land use land cover was clipped from Ethiopian Ministry of water resources (2010). Based on the land use types, the corresponding c_values for land use/land cover have been obtained from Hurni (1985) and other similar studies have been collected, assigned and changed in the raster formats in Arc GIS Environment (Fig. 5, Table 4).

\section{Support practice (P-factor)}

It is the specific soil and water conservation practices to reduce run-off speed and increase infiltration Wischmeier and Smith (1978). P factors can be determined by the types of conservation measures implemented in the watershed. Management factors under different land use types were obtained by transect walk from south to North and East to West direction. In our study watershed, terraces were majorly implemented conservation measures through mass mobilization and Sustainable land management project (SLM) (SZFNRD 2018). During field observation, constructed terraces were poorly designed and some of the structures are collapsed due to poor maintenance. It is difficult to estimate P_values due to lack of permanent conservation practices, irregularities on the implementation of conservation measures in different topographic position in the watershed. The current study employed an alternative method using the combination of land use and slope to estimate P_values as proposed by Wischmeier and Smith (1978). Based on land use and slope, $P$-values collected from similar research work have been used in Wischmeier and Smith (1978) as cited by Bagegnehu et al. (2019) in (Table 5). Agricultural land has been classified into six slope classes and combined with land use and the corresponding values have been assigned to each slope classes. 
Fig. 5 Stations R_factors

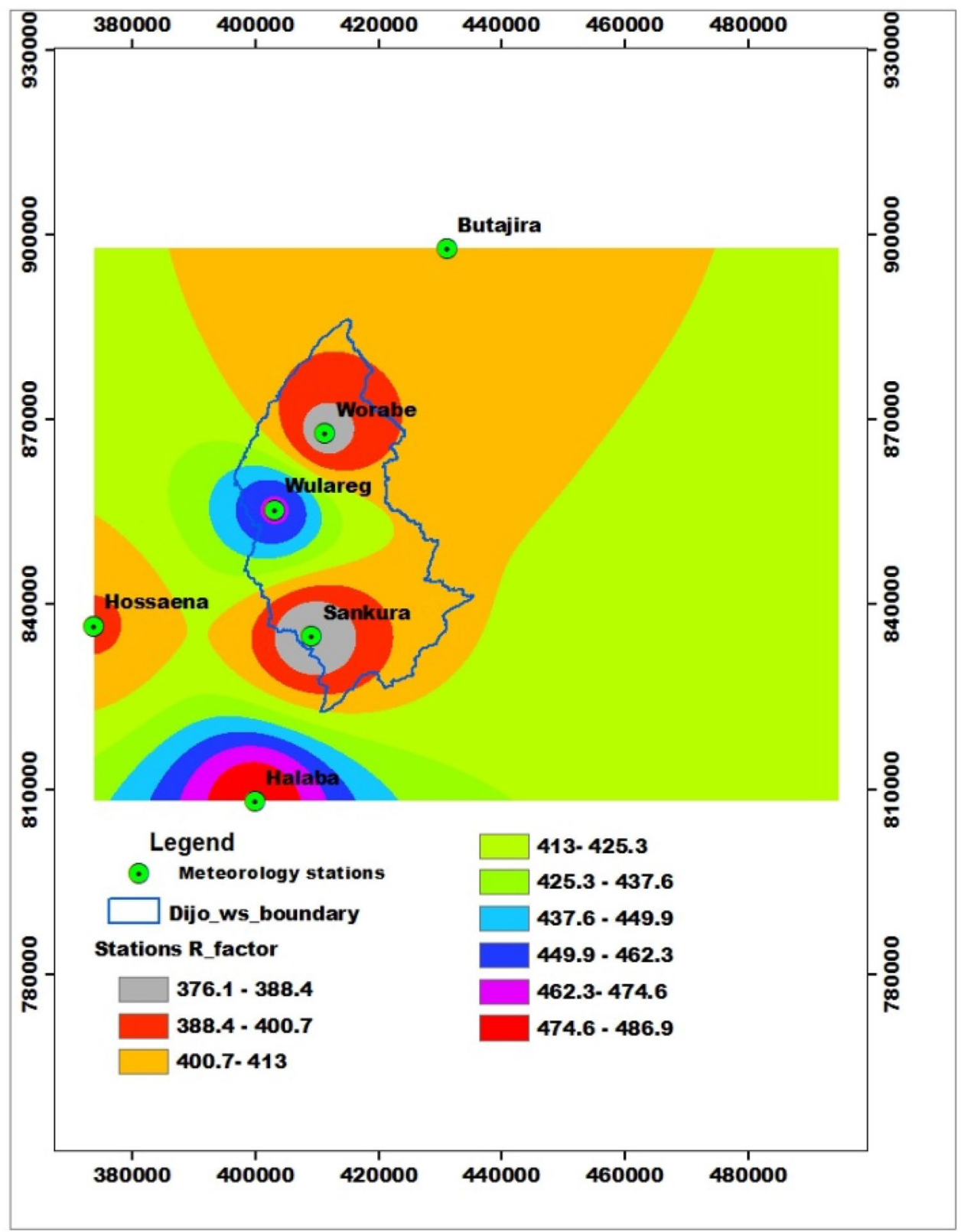

Table 4 Land use types and their respective C-factor values

\begin{tabular}{lll}
\hline Land use & C_factor & References \\
\hline Cop lands & 0.15 & Hurni (1985) \\
Mixed plantation & 0.04 & Wischmeier and Smith (1978) \\
Open shrub lands & 0.17 & Kaltenrieder (2007) \\
Closed shrub lands & 0.16 & Kaltenrieder (2007) \\
Grass lands & 0.05 & Hurni (1985) \\
Woody savannas & 0.08 & Wischmeier and Smith (1978) \\
Savannas & 0.09 & Ozsoy et al. (2012) \\
\hline
\end{tabular}

Table 5 Estimated conservation practice (P_factor values)

\begin{tabular}{lll}
\hline Land use & Slope & P_values \\
\hline Crop lands & $0-5$ & 0.1 \\
& $5-10$ & 0.12 \\
$10-20$ & 0.14 \\
$20-30$ & 0.19 \\
$30-50$ & 0.25 \\
& $50-100$ & 0.33 \\
Other land use & & 1
\end{tabular}




\section{Soil loss analysis}

Quantitative and qualitative analyses were used. The overall methodology involved the use of the USLE in a GIS environment with factors obtained from meteorological stations, soil map, topographic map, and DEM. GIS layers were formed in raster format for both Environmental (RKLS) and management factors ( $\mathrm{C}$ and $\mathrm{P}$ ) as input for the USLE model to generate the contribution of individual factors grid. Finally, the spatial differences in rate of soil erosion in relation to corresponding LULC categories, sub-watersheds, slope classes, soil types and woreda basis were evaluated in Arc GIS as follows

$\mathrm{A}=\mathrm{R} * \mathrm{~K} * \mathrm{LS} * \mathrm{C} * \mathrm{P}$,

where $A=$ Annual soil loss in ton/ha/year, $R=$ Rainfall erosivity factor in $\mathrm{MJ} \mathrm{mm} \mathrm{ha}{ }^{-1}$ year $^{-1} \mathrm{~K}=$ Soil erodibility factor in $\mathrm{thr} \mathrm{MJ}^{-1} \mathrm{~mm}^{-1}$, LS = Slope Steepness and Slope Length factor (dimensionless), $C=$ Cover factor (dimensionless), $p=$ conservation practice factor (dimensionless).

\section{Sediment yield estimation}

The sediment delivery ratio (SDR) denotes the ratio of the sediment yield at a given stream cross section to the gross erosion from the watershed upstream from the measuring point (Julien and Frenette 1998). Using the empirical equations, the sediment yield at the watershed outlet was calculated as follows

$\mathrm{SDR}=\mathrm{A}^{-0.2}$,

where SDR denotes the sediment delivery ratio and area of the watershed. The SDR physically means the ratio of the sediment routed to the outlet over the watershed, both overland and channel. Sediment yield is commonly estimated by the following empirical formula:

Sy $=\mathrm{E} *\left(1 / \mathrm{A}^{0.2}\right)$,

where Sy $=$ Sediment yield (ton) at the watershed out let; $E=$ total erosion (ton); $A=$ watershed area (ha).

\section{Approaches for validation of model results}

Previously, there are no case studies in the specific watershed. Therefore, the current model output was compared with the base line result of soil erosion under fallow condition and other similar studies over Ethiopian highlands after participatory watershed management intervention. Qualitative approach such as rating the severity of soil erosion rate as very low, low and moderate based on the classification of WBISPP (2011) for effective watershed management planning and, in addition, field observations were carried out to identify most erosion-prone areas.

\section{Results}

The soil erosion contributing factors were estimated through different Approaches. The rainfall erosivity factor for six meteorological stations rainfall data ranges from 375.06 to 486.96 for the rainfall of distribution of $912.40 \mathrm{~mm}-1220.44 \mathrm{~mm}$, respectively, as shown in (Table 6 and Fig. 5).

\section{Rainfall Erosivity ( $R$ factor) estimation}

The Average annual rainfall and average $\mathrm{R}$ _factors were estimated for the entire watershed. The rainfall erosivity (R-factor) value of the watershed ranges from 376 to 465 $\mathrm{MJmm} / \mathrm{ha} /$ year with average erosivity value of $408.9 \mathrm{MJmm} /$ ha/year in (Fig. 6).

\section{Soil Erodibility factors (K_factors)}

The major soil types of Dijo watershed were Molic Andosols, Pellic vertisols, chromic luvisols, Haplic Phaeozems, Eutric Cambisols and Lithosols. Molic Andosols covers (37.2\%), Pellic vertisols (19.6\%), Chromic luvisols (17.2\%), Haplic phaeozems (17.1\%), Eutric cambisols (7.6\%) and Lithosols (1.3\%). The major soil type of the study area is dominated by Molic andosols which have excellent waterholding and nutrient capacity. Based on their inherent characteristics, cambisols are erodible of all soil types in the
Table 6 Stations Mean annual rainfall and Erosivity factor

\begin{tabular}{|c|c|c|c|c|c|c|c|}
\hline \multirow[t]{2}{*}{ Stations } & \multicolumn{3}{|l|}{ Locations } & \multirow[t]{2}{*}{ Data duration } & \multirow[t]{2}{*}{ Rainfall } & \multirow[t]{2}{*}{ No of years } & \multirow[t]{2}{*}{ Erosivity } \\
\hline & Longitude & Latitude & Altitude & & & & \\
\hline Sankura & 38.17722 & 7.552889 & 1876 & 2006-2015 & 912.40 & 10 & 376.06 \\
\hline Worabe & 38.19628 & 7.850778 & 2059 & 2006-2018 & 930.10 & 13 & 382.44 \\
\hline Hulbareg & 38.12278 & 7.738306 & 1996 & 1972-2016 & 1160.80 & 44 & 465.49 \\
\hline Hossaena & 37.85614 & 7.567806 & 2306 & 1953-2017 & 975.30 & 64 & 398.71 \\
\hline Butajira & 38.37594 & 8.122611 & 2074 & 1955-2017 & 999.70 & 62 & 407.49 \\
\hline Halaba & 38.09392 & 7.310583 & 1772 & 1989-2019 & 1220.44 & 30 & 486.96 \\
\hline
\end{tabular}


Fig. 6 Watershed R_factors

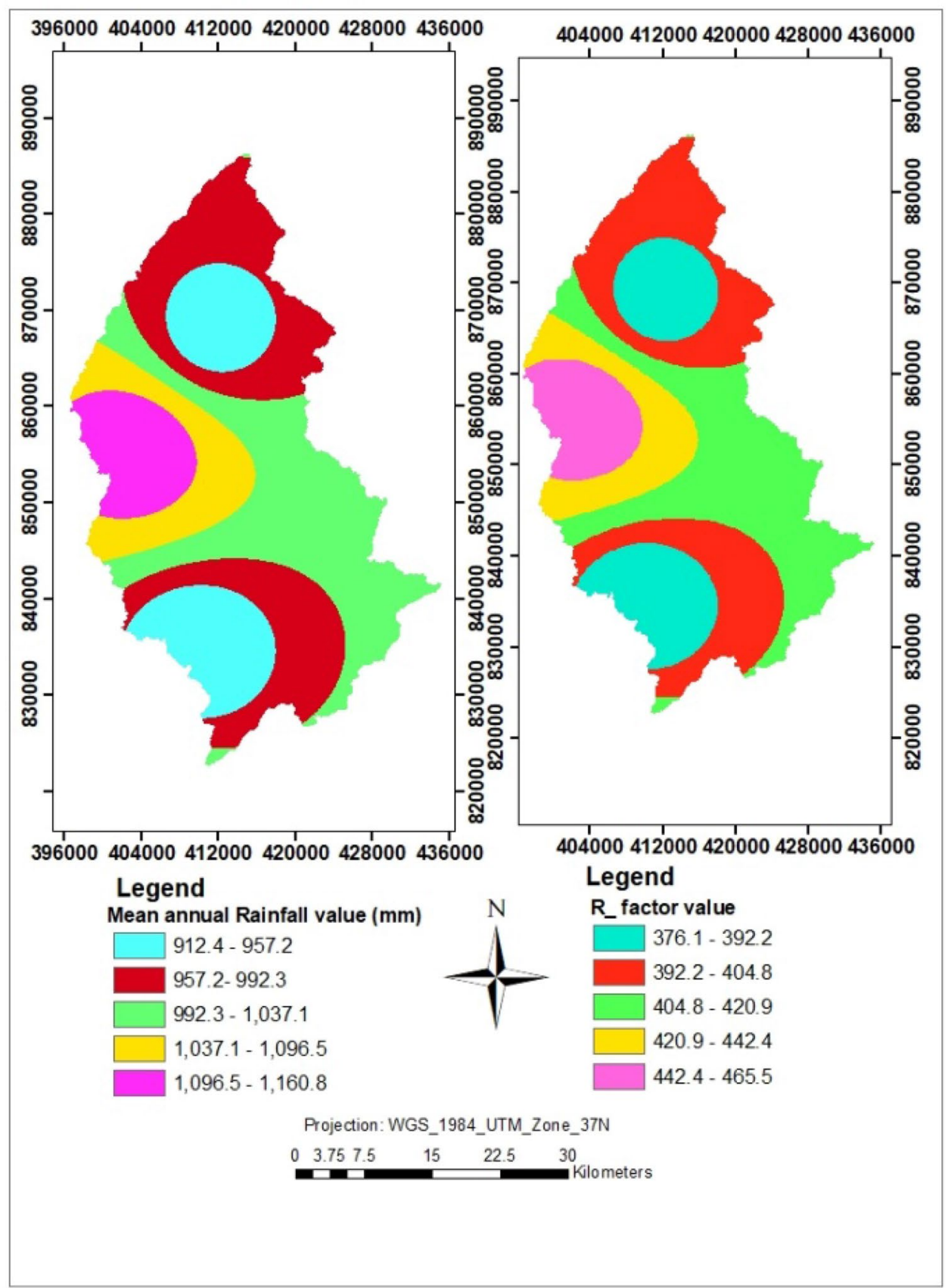

Table 7 Soil erodibility based on their color and soil types

\begin{tabular}{lll}
\hline No & Soil type & $\begin{array}{l}\text { Soil erodibility factor K_val- } \\
\text { ues (metric tons/ha/MJ/mm) }\end{array}$ \\
\hline 1 & Molic Andosols & 0.25 \\
2 & Haplic phaeozems & 0.20 \\
3 & Chromic luvisols & 0.14 \\
4 & Eutric cambisols & 0.35 \\
5 & Pellic vertisols & 0.22 \\
6 & Lithosols & 0.24 \\
\hline
\end{tabular}

area. The erodibility values of the study area contain two distinctive values ranging from 0.14 which is Chromic luvisols soil to 0.35 which is Eutric cambisols (Table 7 and Fig. 7).

\section{Topographic factor map (LS_factor map)}

The slope steepness of the study watershed ranges from 0 to $57 \%$. Slope steepness is classified into five classes. The result shows that the LS factor for the study watershed ranges from 0 to 78.48 . The mean slope length and steepness factor of the study area is 0.56 with standard 


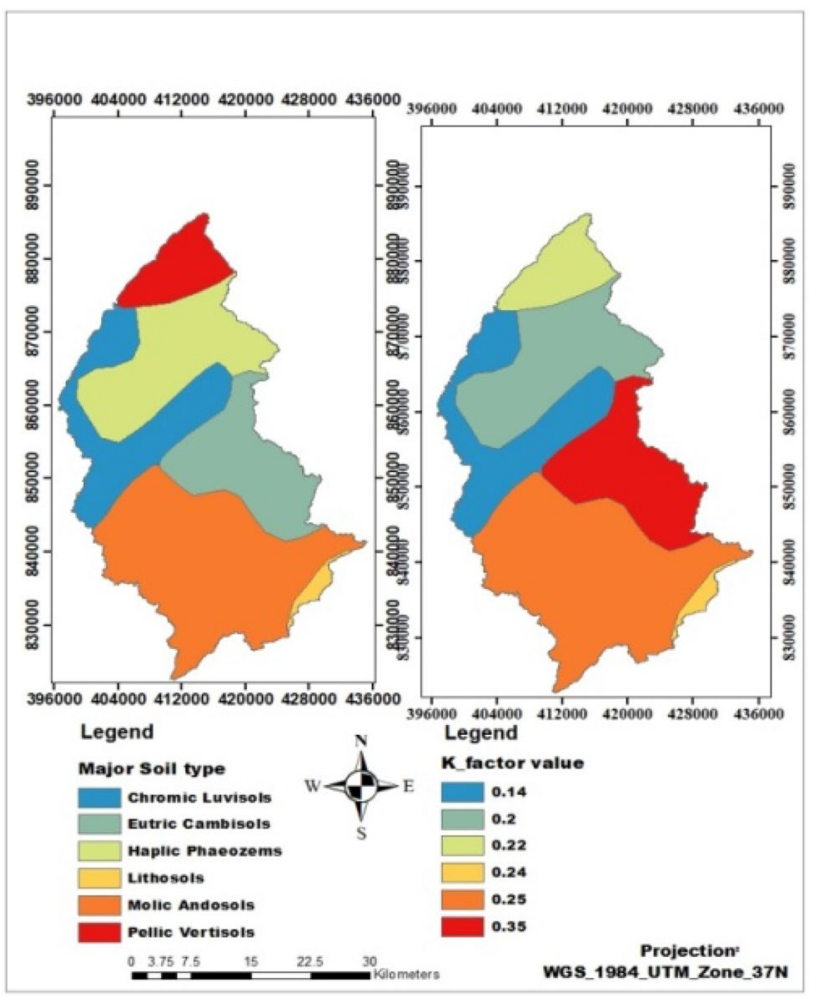

Fig. 7 Major soil types and Soil Erodibility (K_factor) map of the study area

deviation of 0.50 and maximum and minimum values of 78.48 and 0 , respectively (Fig. 8).

\section{Cover factor (C_factor)}

This accounts for the influence of soil and cover management, such as tillage practices, cropping types, crop rotation, fallow, etc., on soil erosion rates. $\mathrm{C}$ factor for the study watershed ranges from 0.04 to 0.17 . The $c$-values of croplands (0.15), mixed plantations (0.04), grasslands (0.05), woody savannas (0.08), Savannas (0.09), closed shrub lands (0.16), open shrub lands (0.17), with the mean values of 0.08 with standard deviation of 0.05 and maximum and minimum value of 0.17 and 0.04 , respectively (Fig. 9).

\section{Conservation practice factors ( $P_{-}$factor)}

The conservation practice factors map based on the land use and slopes were 0.1 to 1 as shown in the (Fig. 10). The lower value of $\mathrm{P}(0.1)$, the more effective the conservation practices. The $\mathrm{P}$ factor value was 1 for other areas as there was no erosion control structures in these areas.

\section{Potential soil loss}

This study tried to quantify and map soil erosion in Dijo watershed. The soil loss range of Dijo watershed is from 0 to $38.09 \mathrm{ton} / \mathrm{ha} / \mathrm{year}$. The average annual soil loss rate was estimated to be 2.2 ton/ha/year. A total of $\mathbf{4 5 6 , 4 1 5 . 6 0}$ ton of soil has been lost annually (Fig. 11).

The mean soil loss rate (2.2 ton/ha/year) of Dijo watershed has been classified into three soil erosion severity classes based on the classification of WBISPP (2011) for effective watershed management planning. 0-3.125 range of soil loss classes share maximum erosion which accounts $84,822 \mathrm{Ha}(68.7 \%)$ and the minimum accounts $1938 \mathrm{Ha}$ (1.57\%) on $>25 \%$ numerical range of soil. The maximum erosion accounts $161,161.8$ ton/year of total soil loss. Whereas the rest low and moderate soil erosion risk classes account $24.7 \%$ and $5.07 \%$, respectively (Table 8 ).

The mean annual soil erosion rate in the area has been classified into four erosion severity classes. As shown in Fig. 12, Dijo watershed was classified into four severity classes. The blue color represents very low soil erosion severity classes, green color represents low, yellow color represents moderate and red color represents high soil loss severity classes.

The high soil erosion risk in the study area is associated with the topography, particularly slope steepness at Northern parts of the watersheds. Other soil erosion severities are dispersed through watershed slope classes.

Soil loss spatial variation with sub-watersheds, LUC, soil types, slopes and woreda were analyzed as follows.

\section{Soil erosion rate by sub-watersheds}

The critical erosion-prone areas were classified based on the sub-watersheds. The potential annual soil loss ranges from 0 in the flat land to 38.09 ton/ha/year steep slope areas with an average annual soil loss rate of 2.2 ton/ha/year. Thus, the mean annual soil loss rate of the watershed (2.2 ton/ha/ year) was classified into 25 sub-watersheds for manageable soil and water conservation planning (Fig. 13). Based on the classification, two sub watersheds fell under very low erosion severity classes ( $0-1$ ton/ha/yr), 22 sub-watersheds fell under low erosion severity classes (1-5 ton/ha/yr). Out of $25 \mathrm{sub}$ watersheds, two sub watersheds $\mathrm{X}$ and $\mathrm{S}$ fall under very low erosion severity classes ( $0-1$ ton/ha/year). 22 subwatershed classes (A, C, D, E, F, G, H, I, J, K, L, M, N, O, P, $\mathrm{Q}, \mathrm{R}, \mathrm{T}, \mathrm{U}, \mathrm{V}, \mathrm{W}, \mathrm{Y}$ ) falls under low erosion severity classes (1-5 ton/ha/year). Whereas, the rest one sub-watershed B falls under Moderate classes (5-10 ton/ha/year).

As compared to the watershed average annual soil loss rate, $\mathbf{1 1}$ sub-watersheds such as $\mathbf{R}, \mathbf{F}, \mathbf{N}, \mathbf{C}, \mathbf{J}, \mathbf{I}, \mathbf{G}, \mathbf{O}, \mathbf{D}, \mathbf{A}$ and $\mathbf{B}$ have erosion rate of 3.1 ton/ha/year which is above 
Fig. 8 LS factor map of the study watershed

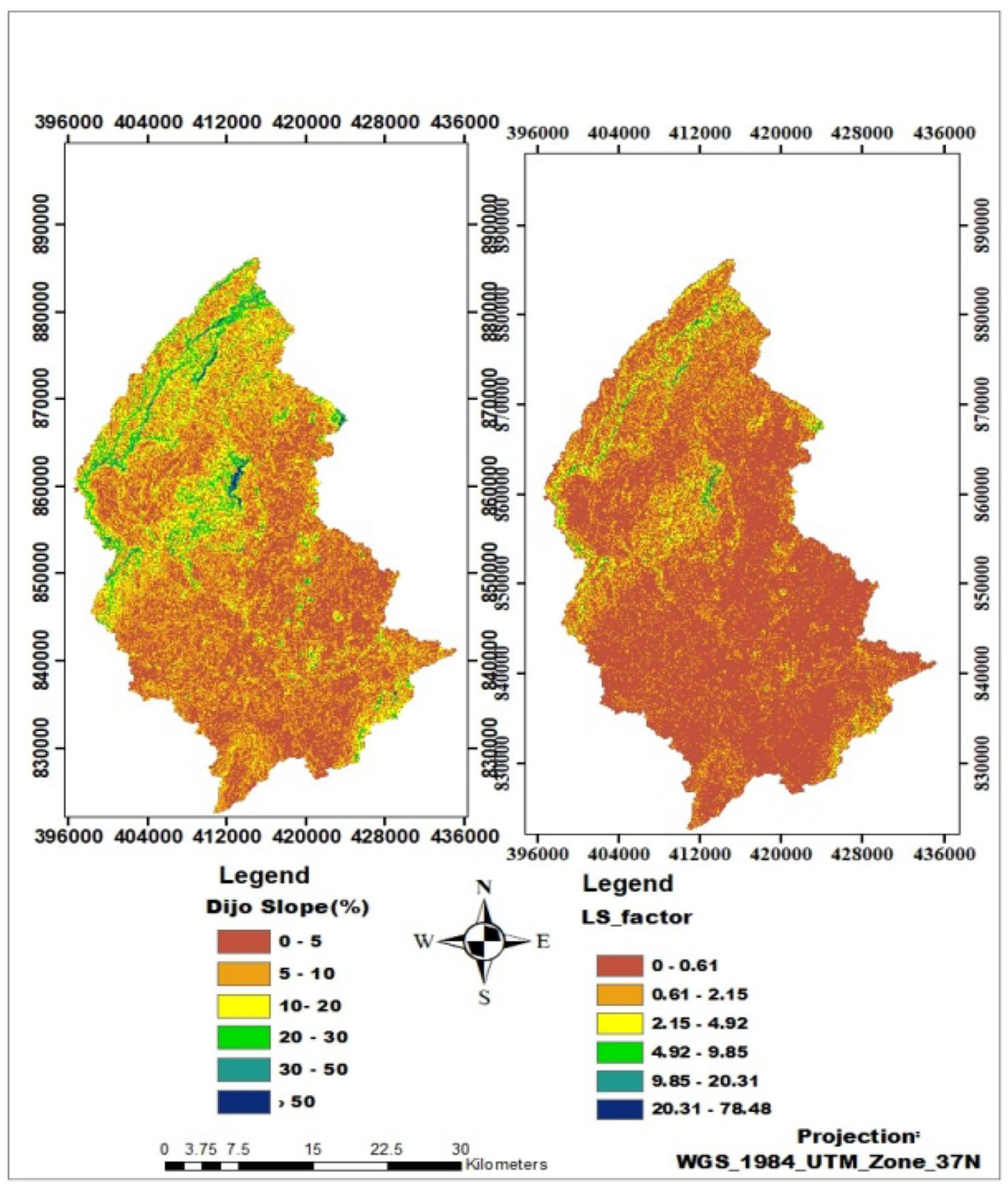

the watershed mean (2.2 ton/ha/year). Whereas, the rest 14 sub-watersheds have average soil loss rate of 1.5 ton/ha/year which is below watershed mean values (Table 9).

\section{Classification and prioritization of sub-watersheds}

Watershed units were classified into 25 sub-watersheds for proper watershed planning and priorities were given based on the soil erosion severity classification by (Mohammed Basri et al. 2019). Based on the analysis, the potential soil loss rate of the sub-watershed ranges from $\mathbf{0 . 8 9}$ to 5.29 ton/ ha/year. Two sub-watersheds ( $\mathrm{X}$ and $\mathrm{S}$ ) were categorized at very low erosion severity classes which covers $6.58 \%$ from total watershed areas. 22 sub-watersheds(A, C, D, E, F, G, H, I, J, K, L, M, N, O, P, Q, R, T, U, V, W and Y) fall under low soil erosion classes which covers $90.74 \%$ of the watershed areas. Whereas, sub-watershed B has moderate soil erosion. This implies that there was spatial variability of soil loss in sub-watersheds (Table 10).

\section{Erosion rate under different land use, slope, soil types and woreda basis}

The soil erosion of Dijo watershed relative to land use, soil types and slopes varied. Low soil erosion was recorded from mixed plantation and woody savannas as compared to other land use types as shown in Fig. 14a. This could be attributed to mixed plantation of acacia species, Eucalyptus globulus, and cupperesus lustanica.

The soil erosion under different soil types was analyzed. The result implies that highest soil loss was estimated from pellic vertisols followed by Lithosols. The lowest erosion rate from Molic Andosols. Lithosols are 
Fig. 9 Land use and cover factor map

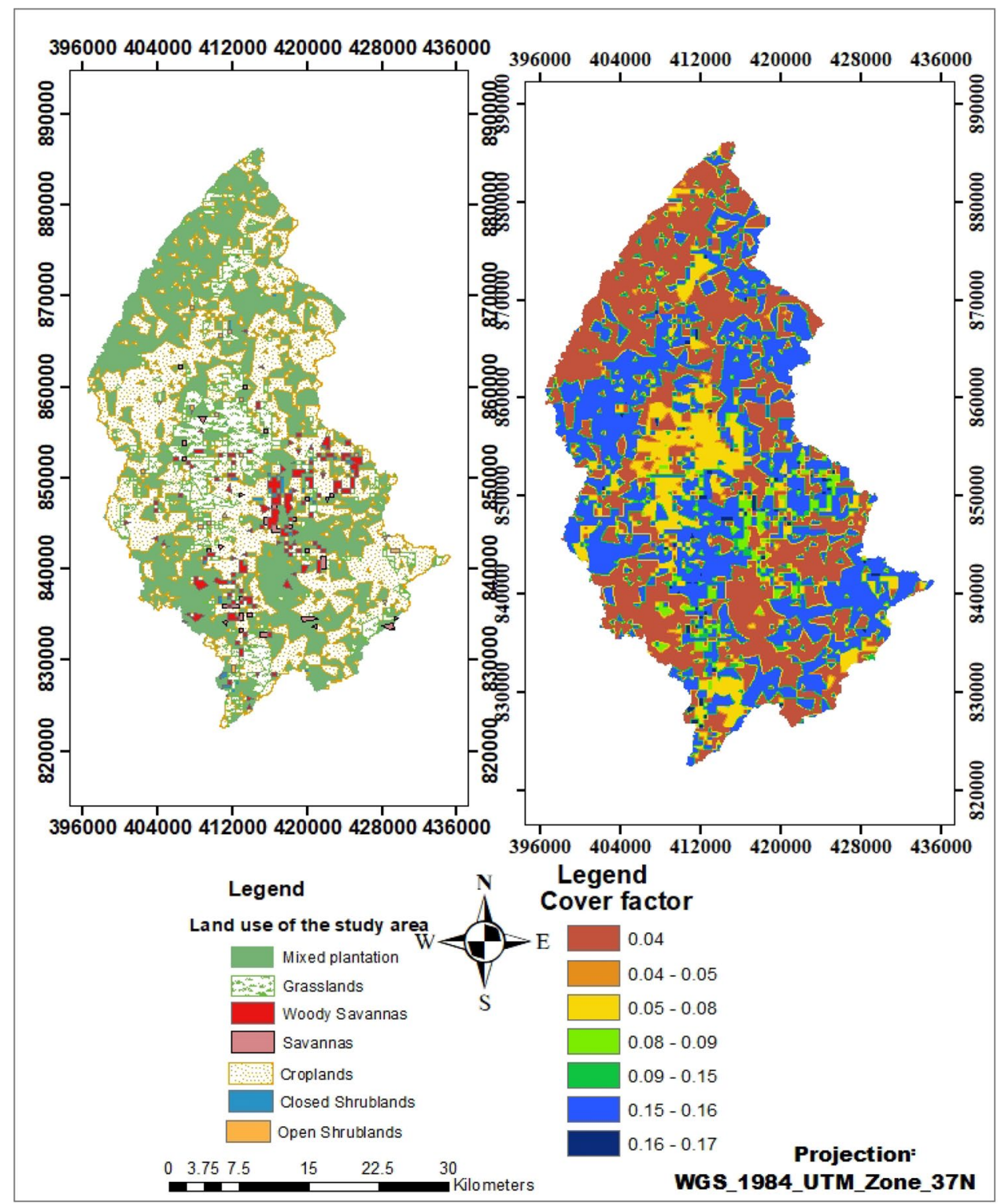

shallow soils consisting of imperfectly weathered rock fragments having sandy clay soil texture classes. This implies that the Lithosols have low water-holding capacity. The lowest soil erosion on Molic Andosols could be due to their good aggregate stability and high permeability to water which make these soils resistant to water erosion.

Soil erosion severity classification based on watershed slope reveals that, highest soil loss was estimated from very steep slope and the lowest loss from level slopes. Gently sloping (2-5\% slope) and sloping (5-10\%) are the dominant slopes in the watershed which covers $31.8 \%$ and $31.4 \%$ from the total watershed, respectively. From the result, 58.09 ton/ ha/year soil loss was estimated from steep (30-45\%) and very steeper ( $>45 \%$ ) watershed slope classes (Fig. 15).

\section{Erosion rate by woreda}

The annual mean soil loss rate for each woreda was estimated and each woreda erosion severities were compared with the tolerable soil loss limit. Soil loss tolerance or $\boldsymbol{T}$ value is the maximum average annual soil loss expressed as tons per acre per year that will permit current production levels to be maintained economically and indefinitely. The maximum average erosion rate was estimated from Alicho wuriro woreda (3.6 ton/ha/year) and the minimum (1 ton/ha/ year) from Sankura woreda (Table 8).

Lanfuro, Sankura and Halaba woreda erosion severity is below the minimum ( 2 ton/ha/year); whereas, Dalocha, Hulbareg, Alicho and Silti woreda have greater than the 


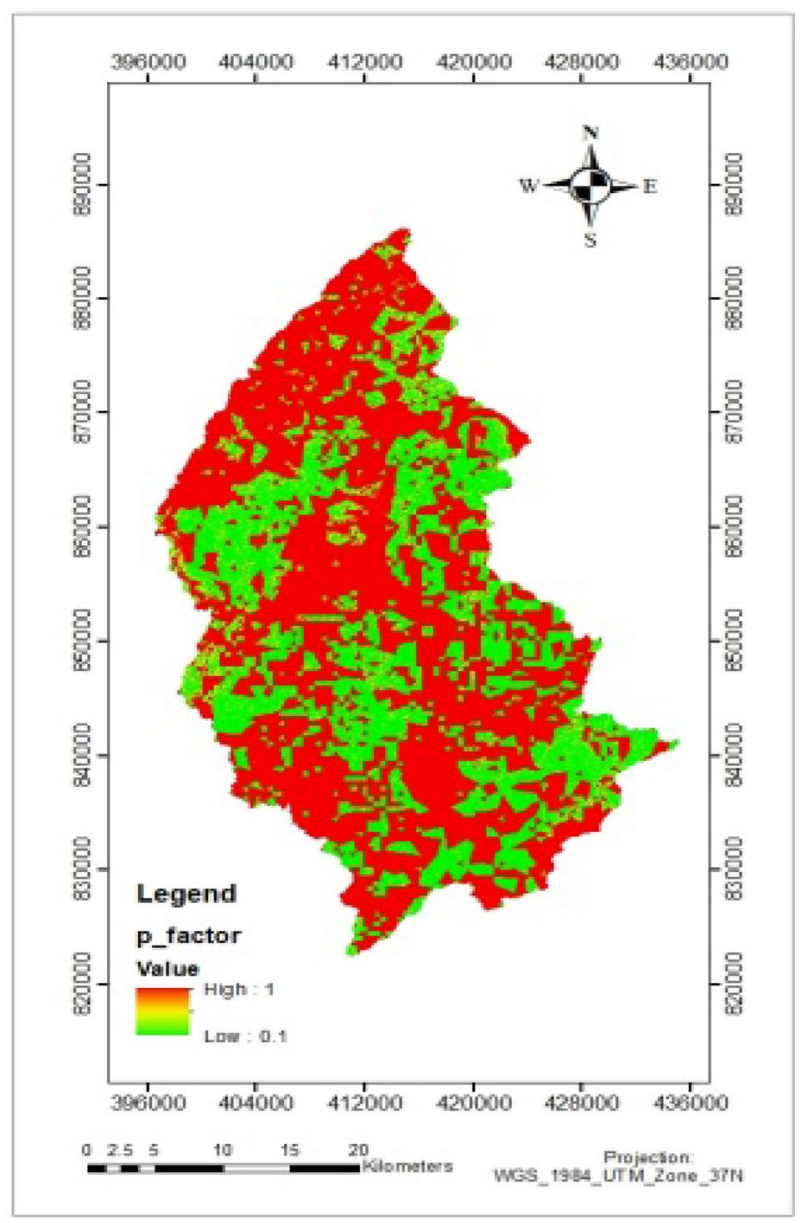

Fig. 10 Conservation practice factor

minimum erosion severity ranges to Ethiopian condition. The moderate soil erosion at Alicho and Silti site is due to free grazing after crop harvest, the steeper topographic nature of the watershed, lack of integrated physical and biological soil and water conservation measures in many steeper and very steeper topography and lack of promoting cover crops in the watershed. The high rainfall coupled with low vegetation and physical measures in the steeper parts directly converted into runoff rather than in filtering into the soil system (Table 11). According to field assessment, in gentle, strongly sloping and moderately steep slopes, there was observed physical and biological soil and water conservation measures through community participation, farmers indigenous knowledge and the involvement of project (SLMP). Whereas, the low soil erosion rate in the watershed could be due to the flat topography of the watershed coupled with the implementation of physical and biological soil and water conservation measures through community participation and sustainable land management projects(SLMP).

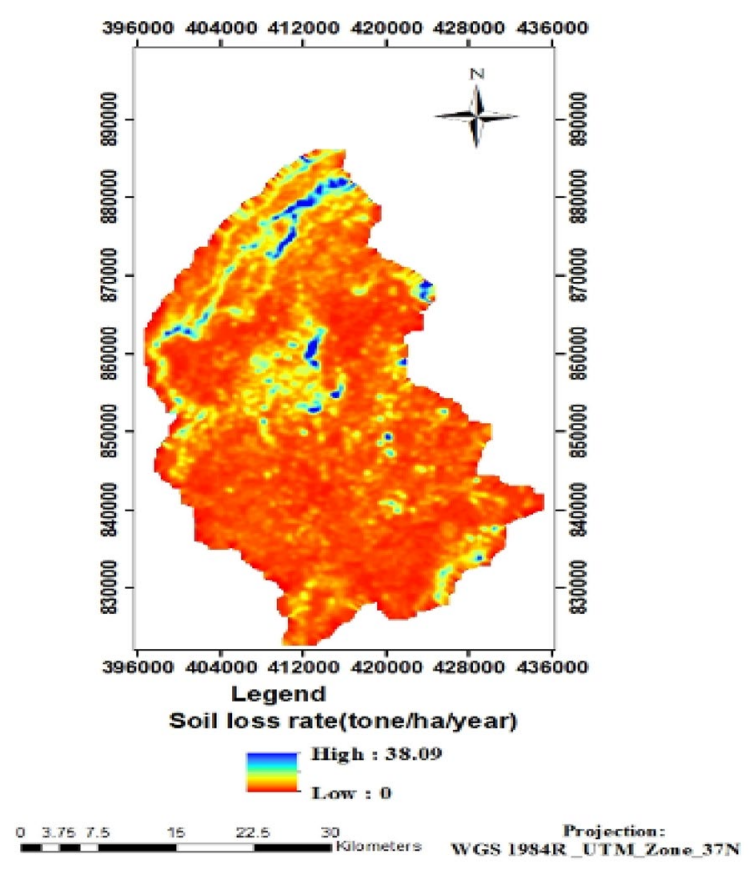

Fig. 11 Soil erosion range of Dijo watershed

Table 8 Annual soil loss rates, severity classes and conservation priority of the study area

\begin{tabular}{|c|c|c|c|c|c|}
\hline \multirow[t]{2}{*}{ No. } & \multirow[t]{2}{*}{ Soil erosion risk } & \multirow{2}{*}{$\begin{array}{l}\text { Numerical } \\
\text { range of } \\
\text { soil }\end{array}$} & \multicolumn{2}{|l|}{ Area } & \multirow{2}{*}{$\begin{array}{l}\text { Total soil } \\
\text { loss (ton/ } \\
\text { year) }\end{array}$} \\
\hline & & & $\mathrm{Ha}$ & $\%$ & \\
\hline 1 & Very low (I) & $0-3.125$ & 84822 & 68.7 & $161,161.8$ \\
\hline 2 & Low (II) & $3.125-6.25$ & 30,415 & 24.7 & $154,508.2$ \\
\hline 3 & Moderate (III) & $6.25-12.5$ & 6220 & 5.04 & $66,927.2$ \\
\hline 4 & High (IV) & $>12.5$ & 1938 & 1.57 & $73,818.4$ \\
\hline Total & & & 123,395 & 100 & $456,415.60$ \\
\hline
\end{tabular}

\section{Discussion}

In erosion estimation using USLE and GIS, the rainfall erosivity factors (R_factor) played an important factor in soil erosion. According to the Fig. 6, annual $\mathrm{R}$ value ranges between 376 and $465 \mathrm{MJmm} / \mathrm{ha} /$ year. The highest value of $\mathrm{R}(466 \mathrm{MJmm} / \mathrm{ha} /$ year) was found on the western parts of the watershed and the lowest value $(375 \mathrm{MJmm} /$ ha/year) found in the northern parts (high elevation area) and lower parts of the watershed (Fig. 6). The inherent characteristics of soil also influence the rate of soil erosion. According to the Fig. 7, the soil erodibility for the watershed ranges from 0.14 to 0.35 metric tons/ha/MJ/ $\mathrm{mm}$. The topographic (LS_factor) value for the watershed is $0-78.48$ (Fig. 8), which is within the ranges of Bekele et al. (2019), who reported that the LS factor for karessa 


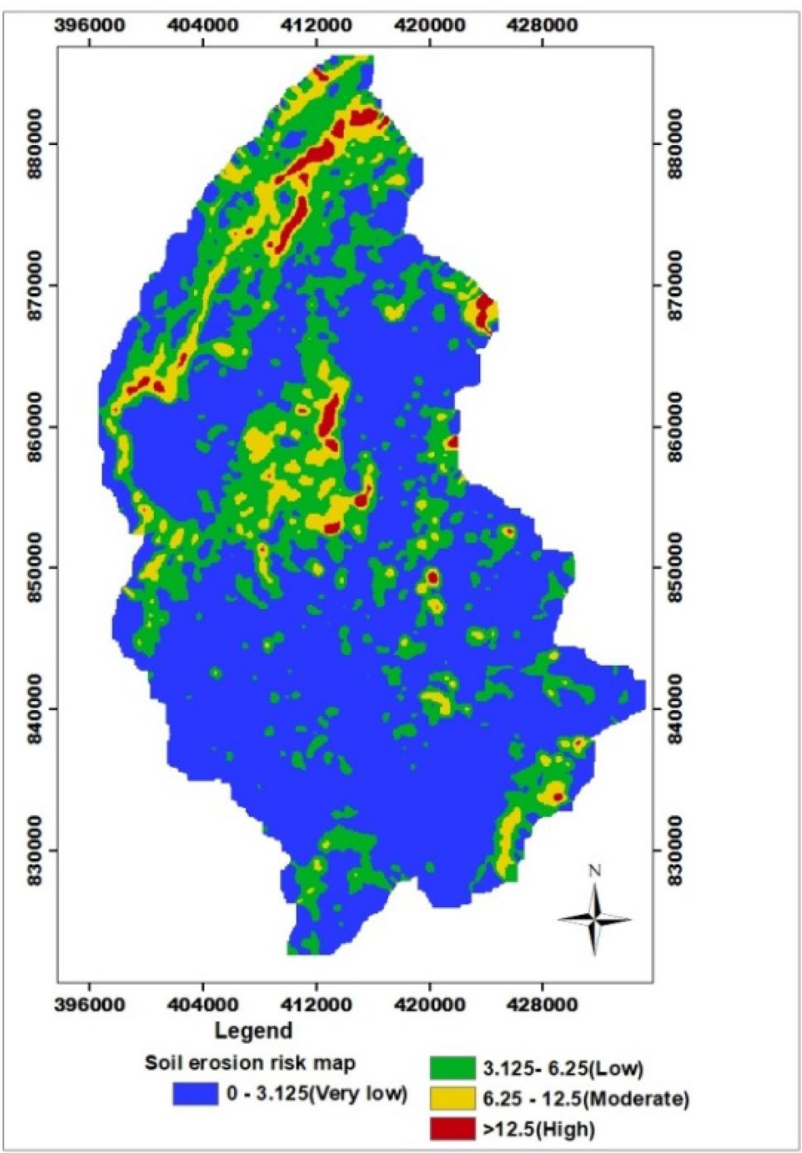

Fig. 12 Soil Erosion risk map of Dijo watershed

watershed Dawuro zone, south west Ethiopia ranges from 0 in flat areas to 154.6 steeper and longer slope area of the watershed.

The mean annual soil losses of Dijo watershed range from 0 in the flat slope to 38.09 ton/ha/year from steep slope areas with the annual average soil loss rate of 2.2 ton/ha/year. The total annual soil losses are $\mathbf{4 5 6 , 4 1 5 . 6 0}$ ton/year. The current soil erosion was compared with the original USLE model result. According to Hurni et al. (2008), the original model result due to erosion of cultivated fields in Ethiopia under standard condition was 42 ton/ha/year. The result is consistent with the finding of Bekele et al. (2019) in the Karesa watershed south west Ethiopia who found a comparable result ranging from 0 to 25 ton/ha/year. The finding was also consistent with the finding of Belayneh et al. (2019), who estimated the annual soil loss ranges from 0.01 to 442.92 ton/ha/year. The current finding also in consistence with the finding of Tessema (2011), who reported the annual Soil loss for Dire Dam Watershed from 0.00 to 263.25 ton/ ha/year, Amsalu and Mengaw(2014), reported the annual soil loss in Jabi Tehinan Woreda ranges from nearly 0 in south and central parts of the area to 504.6 ton/ha/year in steeply sloping mountainous areas of the north and northeastern parts of the catchments. Similarly, the finding of setegn et al. (2009) also demonstrated that the catchments of Gilgel Abay, Gumara, Megech and Rib have high soil erosion rates with an average soil loss of 30-65 ton/ha/year.

The mean annual soil loss rate was analyzed based on the sub-watersheds, soil types, land uses, slopes and woreda basis. Based on the classification, two sub watersheds fell under very low erosion severity classes $(0-1$ ton/ha/yr), 22 sub-watersheds fell under low erosion severity classes (1-5 ton/ha/yr). One sub-watershed fall under Moderate classes (5-10 ton/ha/year). Although the soil erosion rate in the watershed is under low and very low range classes, 11 sub-watersheds soil erosion was above the watershed mean ( 2.2 ton/ha/year) and $\mathbf{1 4}$ sub-watersheds average soil loss is below watershed mean values (Table 9). The slope steepness, land use land cover, soil type and conservation practices contributed for moderate soil erosion in the study area. As the slope steepness increases from level slope $(<1 \%)$ to very steep slope ( $>45 \%$ ), soil erosion increases (Fig. 15). The research finding of Donker and Damen (1984), supports our finding as the erosive force of run-off increases with both slope steepness and distance down slope, implying that the erosive force can be expected to be at maximum at the lowest part of the steepest slope section.

Moderate soil loss was estimated from pellic vertisols followed by Lithosols. This is observed at Northern parts of the watersheds (Alicho wuriro). The lowest erosion rate is from Molic Andosols. The highest soil loss in vertisols could be due to their low infiltration rates when wet and relatively high erodibility. The shallow soil depth coupled with the sandy clay soil texture characteristics of Lithosols leads to low water-holding capacity soil which contributed for comparable soil loss with pellic vertisols. The lowest soil erosion on Molic Andosols could be due to their good aggregate stability and high permeability to water which make these soils resistant to water erosion.

The result of this study was compared with the original model result. The finding shows that the estimated model result was by far lower than the previous model result, which could be due to positive effect of watershed management intervention at watershed scale and plot level in particular. The current soil erosion level was compared with the tolerable soil loss limit to Ethiopian condition. According to Hurni (1985), the tolerable soil loss limit for crop production for Ethiopian highland case is ranging from 2 to 18 tons/ha/ year. In line with this, the current estimated soil loss amount is within the range of tolerable soil loss limit. In general, 64,655 ha $\mathbf{5 2 . 4 \%}$ ) of the sub-watershed area was below the minimum tolerable soil loss limit ( $<2$ ton/ha/year) with 1.5 ton/ha/year average rate of soil loss. 58,740 ha $(47.6 \%)$ of the sub-watershed area was greater than the minimum tolerable soil loss limit with average annual soil loss rate of 3 
Fig. 13 Sub-watersheds of Dijo watershed

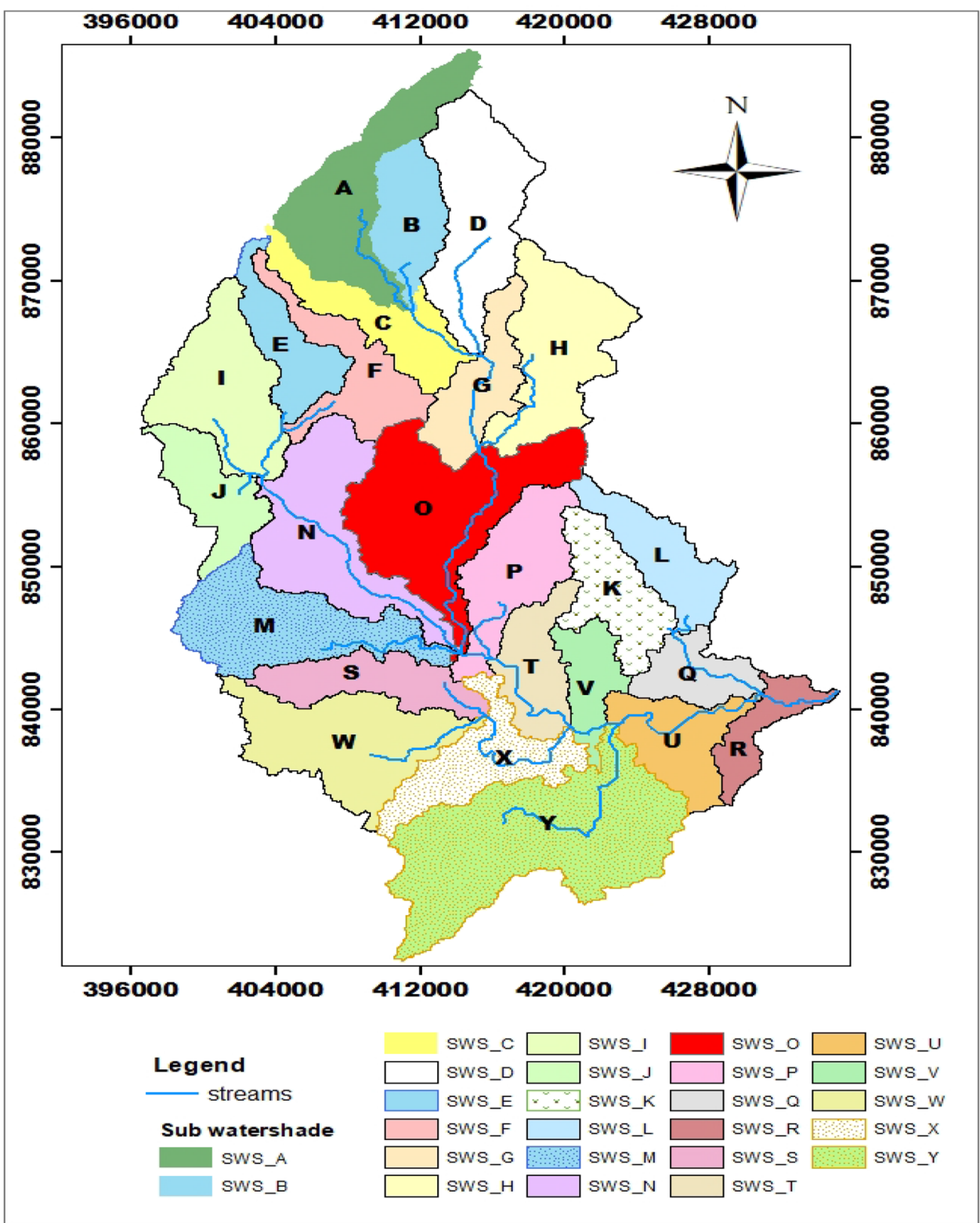

ton/ha/year. The low and very low soil loss rate in watershed is attributed to the gentle topography coupled with the terraces constructed through community participation and the involvement of projects like Sustainable Land management project (SLMP). Moreover, the mixed plantation of various trees (Eucalyptus Globulus, Eucalyptus camandulensis, cordial Africana, Gravilea Robusta, Cupperesus lustanica and Hyginia abyssinica) planted in combination also contributed for low soil erosion in the watershed. According to the assessment and documentation report of Bekele et al. (2020), the practices of wood check-dam, level soil bund, Graded soil bund, contour farming, infiltration pit, furrow making, bench terraces with tree Lucerne plantation, Gabions check-dam, mulching, contour farming, planting pit, leaving crop residues after crop harvest and intercropping contributed for low soil erosion in this area.

\section{Sediment yield}

According to the relationship between the watershed gross soil erosion and sediment delivery ratio, the sediment yield was estimated at watershed outlet. The result reveals that from the gross 456,415.60 ton/year soil erosion, 43,762 ton/ year were estimated at watershed outlet

Sy $=E *\left(1 / A^{0.2}\right)$, 
Table 9 Soil loss by subwatersheds

\begin{tabular}{|c|c|c|c|c|c|c|}
\hline Rank & $\begin{array}{l}\text { Sub water } \\
\text { shade code }\end{array}$ & Area (Ha) & $\begin{array}{l}\text { Area cover- } \\
\text { age }(\%)\end{array}$ & $\begin{array}{l}\text { Range of soil loss } \\
\text { (ton/ha/year) }\end{array}$ & $\begin{array}{l}\text { MSL (ton/ } \\
\text { ha/year) }\end{array}$ & Priority level \\
\hline 1 & B & 3271 & 2.65 & $0.77-31.49$ & 5.29 & Moderate \\
\hline 2 & $\mathbf{A}$ & 6529 & 5.29 & $0.68-15.54$ & 3.86 & Low \\
\hline 3 & D & 6900 & 5.59 & $0.26-22.75$ & 3.4 & Low \\
\hline 4 & $\mathbf{O}$ & 9283 & 7.52 & $0.33-38.09$ & 3.28 & Low \\
\hline 5 & G & 3429 & 2.78 & $0.16-26.67$ & 2.96 & Low \\
\hline 6 & $\mathbf{I}$ & 5959 & 4.83 & $0.27-16.07$ & 2.77 & Low \\
\hline 7 & $\mathbf{J}$ & 3292 & 2.67 & $0.14-10.81$ & 2.63 & Low \\
\hline 8 & $\mathbf{C}$ & 3806 & 3.08 & $0.16-10.88$ & 2.62 & Low \\
\hline 9 & $\mathbf{N}$ & 7281 & 5.9 & $0.25-11.97$ & 2.52 & Low \\
\hline 10 & $\mathbf{F}$ & 3843 & 3.11 & $0.27-11.60$ & 2.35 & Low \\
\hline 11 & $\mathbf{R}$ & 2034 & 1.65 & $0.14-15.68$ & 2.28 & Low \\
\hline 12 & $\mathbf{E}$ & 3113 & 2.52 & $0.25-8.74$ & 2.14 & Low \\
\hline 13 & $\mathbf{T}$ & 3257 & 2.64 & $0.38-16.27$ & 1.89 & Low \\
\hline 14 & $\mathbf{P}$ & 4733 & 3.84 & $0.16-16.85$ & 1.76 & Low \\
\hline 15 & $\mathbf{V}$ & 2334 & 1.89 & $0.25-10.63$ & 1.69 & Low \\
\hline 16 & $\mathbf{K}$ & 3856 & 3.12 & $0.25-16.58$ & 1.68 & Low \\
\hline 17 & $\mathbf{H}$ & 6336 & 5.13 & $0.14-15.04$ & 1.67 & Low \\
\hline 18 & $\mathbf{Q}$ & 2509 & 2.03 & $0.21-6.72$ & 1.59 & Low \\
\hline 19 & $\mathbf{U}$ & 3693 & 2.99 & $0.19-10.36$ & 1.55 & Low \\
\hline 20 & $\mathbf{L}$ & 3567 & 2.89 & $0.23-12.91$ & 1.52 & Low \\
\hline 21 & $\mathbf{M}$ & 6552 & 5.31 & $0.20-7.21$ & 1.42 & Low \\
\hline 22 & $\mathbf{Y}$ & 12,690 & 10.28 & $0.06-10.55$ & 1.38 & Low \\
\hline 23 & $\mathbf{W}$ & 7004 & 5.68 & $0.02-4.24$ & 1.14 & Low \\
\hline 24 & $\mathbf{X}$ & 4534 & 3.67 & $0.23-3.5$ & 1 & Very low \\
\hline \multirow[t]{2}{*}{25} & $\mathbf{S}$ & 3590 & 2.91 & $0.18-5.52$ & 0.89 & Very low \\
\hline & Total & 123,395 & & Mean & & \\
\hline
\end{tabular}

$M S L$ mean soil loss

\begin{tabular}{llllrr}
\hline $\begin{array}{l}\text { Soil loss (t/ha/ } \\
\text { year) }\end{array}$ & Severity classes & $\begin{array}{l}\text { Priority } \\
\text { classes }\end{array}$ & Sub-watersheds & \multicolumn{2}{l}{ Area } \\
\cline { 4 - 6 } & & & Ha & $\%$ \\
\hline $0-1$ & Very Low & IV & X and S & 8124 & 6.58 \\
$1-5$ & Low & III & A, C, D, E, F, & 112,000 & 90.74 \\
& & \multicolumn{4}{c}{ G,H,I,J,K,L,M,N,O,P, Q,R,T, } \\
$5-10$ & Moderate & II & B & 3271 & 2.68 \\
\hline
\end{tabular}

Table 10 Prioritization of subwatershed for proper planning low and low soil erosion severity classes covering $97.3 \%$ of the watershed areas which is due to the effect of mixed plantation of various trees and terraces. $47.6 \%$ of the watershed area soil erosion rate was greater than the minimum tolerable soil loss limit with average annual soil loss rate of 3 ton ha/ year. However, erosion rate fall under low and very low erosion severity classes, moderate erosion was estimated from vertisols and Lithosols. The characteristics of soil, watershed topography (gently sloping and sloping), lack of vegetation cover, cultivation of steep slope without engineering measures, free grazing and sand extraction contributed for 
Fig. 14 a Soil loss with respect to land use b soil loss with respect to soil types
Fig. 15 Soil loss with respect to slope
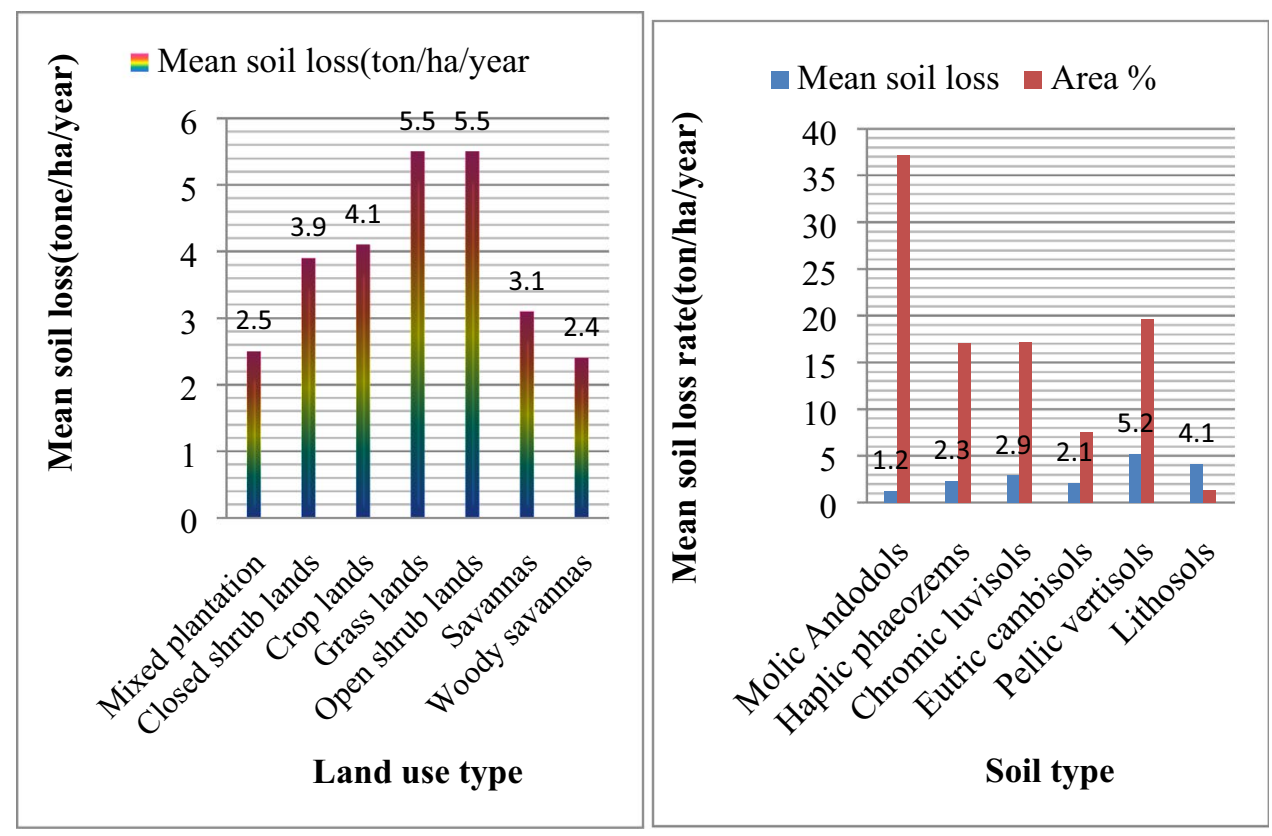

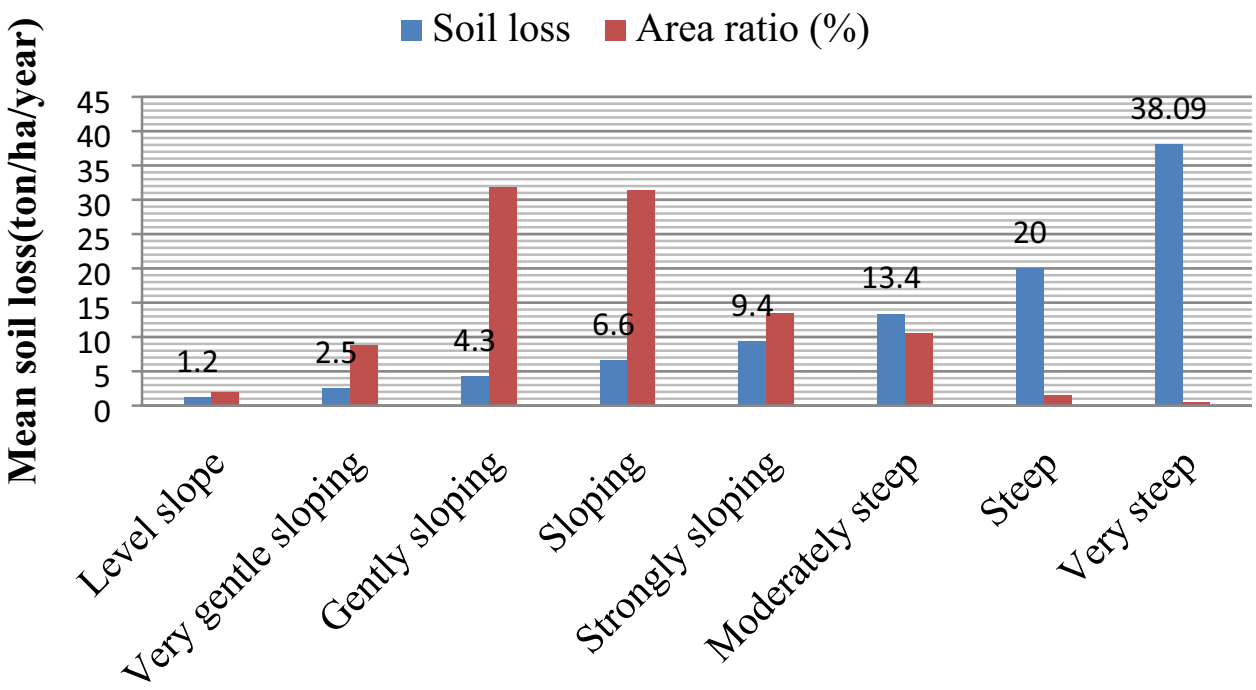

Slope class
Table 11 Soil erosion rate by woreda

\begin{tabular}{lll}
\hline Woreda & Soil loss range & $\begin{array}{l}\text { Mean soil loss } \\
\text { (ton/ha/year) }\end{array}$ \\
\hline Silti & $0-25.25$ & 3.2 \\
Alicho & $0-31.49$ & 3.6 \\
Hulbareg & $0-20.58$ & 2.6 \\
Dalocha & $0-38.09$ & 2.2 \\
Lanfuro & $0-12.90$ & 1.7 \\
Sankura & $0-7.60$ & 1.0 \\
Halaba & $0-15.68$ & 1.4 \\
\hline
\end{tabular}

moderate soil erosion. This erosion has been observed at northern parts of the watersheds (Alicho wuriro. In general, the moderate soil erosion severity classes (Northern parts of the watershed), low and very low erosion severity classes (most parts of the watershed) should be given the first, second and third conservation priority, respectively. It is also quantified that from the gross soil erosion, 43,762 ton/year (9.6\%) reach at watershed outlet as sediment yield. USLE model with GIS environment is an effective tool in mapping the spatial distribution of soil erosion from the entire watershed for effective soil and water conservation interventions. 
Based on the finding, the following points should be recommended

1. The Moderate and Low soil erosion severity areas should be managed through terracing, inter-cropping, contour farming, strip cropping, conservation tillage, mulching and biological stabilizers based on their slope range, soil type and land use type. The moderate soil erosion in Litho sols should be managed by applying the practices of increasing water-holding capacity through inter-cropping, mulching. Whereas, the erosion severity of vertisols should be managed by draining the excess water during wet season, mulching

2. Free grazing and cultivation of steep slope(Northern parts) contributed for moderate soil erosion in the watershed should be managed by cut-carry system, limiting the number of cattle units to be grazed in the specific plot of land and leaving the marginal steep slope areas with no ground covers for natural regeneration

3. The current finding on erosion was evaluated based on the past 10-year land use land cover scenario. Therefore, the soil erosion could be reduced if the current land use land cover scenario is considered.

\section{Limitation of the study and the need for future research}

The USLE model does no account Gully erosion in the watershed. Soil erosion could accurately be estimated if and only if the extent and distribution of gullies should be measured. Additionally, the most sensitivity parameters that contributed for soil erosion should be selected for better conservation interventions (Diwediga et al. 2018). Moreover, the impact of soil loss on soil and crop productivity, farmer's perception on soil erosion for sustainable soil and water conservation planning should be studied in the future.

Acknowledgments The authors thank Worabe Agricultural Research center for facilitating the required resources to complete the field work. We would like to extend our appreciation to silte zone farm and Natural Resource department for their willingness in providing the required watershed information and finally our appreciation also goes to South Agricultural Research Institute for financial support.

Author contributions BB has led overall research activities like proposing research, data compilation, data entry and processing, data analysis, and interpretation of the result and writing up full manuscript. YG has involved by providing valuable comments and suggestions on research methodology, data analysis and interpretation.

\section{Compliance with ethical standards}

Conflict of interest The authors have not declared any conflict of interests.
Availability of relevant data and materials The required data collected for analysis are included in the manuscript. The corresponding author provides all the data set as per the request and ready to clarify the manuscript which is not clear.

Consent for publication We all have agreed to submit our final manuscript for Modeling Earth Systems and Environment Research journal and approved the submission.

Open Access This article is licensed under a Creative Commons Attribution 4.0 International License, which permits use, sharing, adaptation, distribution and reproduction in any medium or format, as long as you give appropriate credit to the original author(s) and the source, provide a link to the Creative Commons licence, and indicate if changes were made. The images or other third party material in this article are included in the article's Creative Commons licence, unless indicated otherwise in a credit line to the material. If material is not included in the article's Creative Commons licence and your intended use is not permitted by statutory regulation or exceeds the permitted use, you will need to obtain permission directly from the copyright holder. To view a copy of this licence, visit http://creativecommons.org/licenses/by/4.0/.

\section{References}

Adinarayana J, Rao KG, Krishna NR, Venkatachalam P, Suri J (1999) A rule-based soil erosion model for a hilly catchment. Catena 37:309-318

Amsalu T, Mengaw A (2014) GIS based soil loss estimation using RUSLE model: the case of Jabi Tehinan Woreda, ANRS, and Ethiopia. Nat Resour 5:616-626. https://doi.org/10.4236/ nr.2014.511054

Amsalu A, Stroosnijder L, de Graaf J (2007) Long-term dynamics in land resource use and the driving forces in the Beressa watershed, highlands of Ethiopia. J Environ Manag 83(4):448-459

Assefa TT, Jha MK, Tilahun SA, Yetbarek E, Adem AA, Wale A (2015) Identification of erosion hotspot area using GIS and MCE technique for koga watershed in the Upper Blue Nile Basin, Ethiopia. Am J Environ Sci 11(4):245-255. https://doi.org/10.3844/ ajessp.2015.245.255

Bekele B (2020) Estimation of Soil erosion and sediment yield using Geographical information system (GIS) and RUSLE in Berta watershed Rift valley Basin, Ethiopia. Global Journal of Science Frontier Research: D Agriculture and Veterinary (Article under press)

Bekele B, Muluneh A, Wondrade N (2019) Geographic Information System (GIS) based soil loss estimation using Universal Soil Loss Equation Model (USLE) for soil conservation planning in Karesa Watershed, Dawuro Zone, and South West Ethiopia. Int J Water Resour Environ Eng 11(8):143-158. https://doi.org/10.5897/ IJWREE2018.0820

Bekele B, Gemi Y, Habtemariam T, Ademe D (2020) Assessment and documentation of indigenous and introduced soil and water conservation practices in the case of Silte and Gurage Zone, SNNPR, Ethiopia. Global Journal of Science Frontier Research: D Agriculture and Veterinary Volume 20 Issue 5 Version 1.0 Year 2020 Types: Double Blind Peer Reviewed International Research Journal Publisher: Global Journals Online ISSN: 2249-4626 \& Print ISSN: 0975-5896

Belayneh M, Yirgu T, Tsegaye D (2019) Effects of soil and water conservation practices on soil physicochemical properties in Gumara watershed, Upper Blue Nile Basin, Ethiopia. Ecol Process. https ://doi.org/10.1186/s13717-019-0188-2 
Cerdà A, Doerr SH (2008) The effect of ash and needle cover on surface runoff and erosion in the immediate post-fire period. Catena 74:256-263

Deniz E, Recep E, Isa C (2008) Erosion analysis of sahim creek watershed (NW of Turkey) using GIS based on RUSLE (3d) method. J Appl Sci 8:49-58

Diwediga B, Bao LQ, Agodzo SK, Tamene LD, Wala K (2018) Modelling soil erosion response to sustainable landscape management scenarios in the Mo River Basin (Togo, West Africa). Sci Total Environ 625:1309-1320

Donker NHW, Damen MCJ (1984) Gully system development and an assessment of gully initiation risk in Miocene deposits near Daroca - Spain. Z.Geomorph.Suppl.Bb., 49: 37-50

FAO (1984) Ethiopian highland reclamation study (EHRS). Final Report, Vol: 1 and 2, Rome

Fistikogli O, Harmancioglu NB (2002) Integration of GIS with USLE in assessment of soil erosion. Water Resour Manag. 16:447-467

Food and Agriculture Organization (FAO) (2012) A national soil model of Ethiopia a geo statistical approach to create a national soil map of Ethiopia on the basis of an SRTM 90 DEM and SOTWIS soil data. Master's Thesis. Faculty of Natural Sciences University of Bern, Switzerland, pp 126

Gebrehiwot SG, Bewket W, Gärdenäs AI, Bishop K (2014) Forest cover change over four decades in the Blue Nile Basin, Ethiopia: comparison of three watersheds. Reg Environ Change 14:253-266

Haregeweyn N, Poesen J, Nyssen J, Govers G, Verstraeten G, Vente J, Deckers J, Moeyersons J, Haile M (2008)Sediment yield variability in Northern Ethiopia: a quantitative analysis of its controlling factors

Helldén U (1987) An assessment of woody biomass, community forests, land use and soil erosion in Ethiopia. A Feasibility Study on the Use of Remote Sensing and GIS-analysis for Planning Purposes in Developing Countries. Lund Studies in Geography, Ser. C. General, Mathematical and Regional Geography, No. 14, Lund, Sweden

Hurni H (1984) Soil erosion and soil conservation in agricultural ecosystems: ethiopia and northern. Thailand 2:131-132

Hurni H (1985) Erosion-productivity-conservation systems in Ethiopia. In: Proceedings of 4th international conference on soil conservation, Maracay, Venezuela, 3-9 November, pp 654-674

Hurni H (1993) Land degradation, famines and resource scenarios in Ethiopia. pp 27-62. In: Pimentel D(Ed) World Soil Erosion and Conservation. Cambridge

Hurni H, Herweg K, Portner B, Liniger H (2008) Soil Erosion and conservation in global agriculture. In: Braimoh AK, Vlek PLG (eds) Land use and soil resources. Springer, Dordrecht, pp 41-71

Julien PY, Frenette M (1998) Physical processes groverning reservoir sedimentation. In: Conference on reservoir sedimentation (pp. 121-142). Fort Collins, Colorado

Kaltenrieder J (2007) Adaptation and validation of the universal soil loss equation (USLE) for the Ethiopian-Eritrean Highlands. MSc Thesis, University of Berne, Centre for Development and Environment Geographisches Institut

Kruger HJ, Berhanu F, Yohannes GM, Kefeni K (1995) Inventory of indigenous soil and water conservation measures on selected sites in the Ethiopian Highlands, p 34

Lal R (2001) Soil degradation by Erosion. School of Natural Resources, The Ohio State University, Columbus, Ohio, USA. Land Degrad Dev 12:519-539

Lu D, Li G, Valladares GS, Batistella M (2004) Mapping soil erosion risk in Rondonia, Brazilian Amazonia: using RUSLE, remote sensing and GIS. Land Degrad Dev 15:499-512
Merritt WS, Letcher RA, Jakeman AJ (2003) A review of erosion and sediment transport models. Environ Model Softw 18(8-9):761-799

Morgan RPC (1995) Soil erosion and conservation, 2nd edn. Longman Group, Har-low

Ozsoy G, Aksoy E, Dirim MS (2012) Determination of soil erosion risk in the mustafakemalpasa River Basin, Turkey, using the revised universal soil loss equation, geographic information system, andremote sensing July 2012. Environ Manag 50:679-694. https://doi.org/10.1007/s00267-012-9904-8

Pelton J, Frazier E, Pickilingis E (2012) Calculating slope length factor (LS) in the (revised) universal soil loss equation (RUSLE) to the Ethiopian highlands

Renard KG, Foster GR, Weesies GA, McCool DK, Yoder DC (1997) Predicting soil erosion by water: a guide to conservation planning with the Revised Universal Soil Loss Equation (RUSLE) in Washington. DC, USA. Vol: 200(703), p 384

Ritchie JC, Nearing MA, Ritchie CA (2003) Patterns of soil erosion and redeposition on lucky hills watershed, walnut gulch experimental watershed, Arizona. 61(2-3):122-130. https://doi.org/10.1016/j. catena.2005.03.012

Setegn SG, Yohannes F, Quraishi S, Chowdary VM, Mal BC (2009) Impact of land use/land cover transformations on Alemaya Lake, Ethiopia. J Indian Water Resour Soc 29(3)

Star JL, Estes JE, Gwire KCM (1997) Integration of geographic information systems and remote sensing. Cambridge University Press, Cambridge

Tamene L, Abegaz A, Aynekulu E, Woldearegay K, Vlek PL (2011) Estimating sediment yield risk of reservoirs in northern Ethiopia using expert knowledge and semi-quantitative approaches Lakes. Reserv Res Manag 16:293-305. https://doi.org/10.111 1/j.1440-1770.2011.00489.x

Tessema I (2011)Soil erosion risk assessment with RUSLE and GIS in Dire Dam Watershed (unpublished)

Tsegaye G, Gebremichael A (2014) Review on overall status of soil and water conservation system and its constraints in different agro ecology of southern Ethiopia. J Nat Sci Res 4(7):59-69

Veihe A, Rey J, Quinton JN, Strauss P, Sancho FM, Somarriba M (2001) Modelling of event-based soil erosion in Costa Rica, Nicaragua and Mexico: evaluation of the EUROSEM model. Catena 44:187-203

Wang Z, Shao M, Lei T (2003) Tillage erosion in loess area and the spatial pattern of contribution to total erosion. J Ecol 23(7):1328-1335

WBISPP (Woody Biomass Inventory and Strategic Planning Project) Southern Nations, Nationalities, and People's Regional State (SNNPR) (2011) A strategic plan for the sustainable development, conservation, and management of the woody biomass resources Woody Biomass Inventory and Strategic Planning Project. Hawassa, Ethiopia

Wischmeier W, Smith D (1965) Predicting rainfall erosion losses from Cropland East of the Rocky Mountains: guide for selection of practices for soil and water conservation. U.S. Department of Agriculture Handbook No. 537

Wischmeier WH, Smith DD (1978) Predicting rainfall erosion losses: guide to conservation planning; Agriculture Handbook No. 537; U.S. Department of Agriculture: Washington, DC, USA

Publisher's Note Springer Nature remains neutral with regard to jurisdictional claims in published maps and institutional affiliations. 